\title{
DNEVNIK RADA POPISIVANJA GRADIVA CRKVENIH ARHIVA POREČKE I PULSKE BISKUPIJE TE PAZINSKE APOSTOLSKE ADMINISTRATURE (18. PROSINCA 1970. - 28. LISTOPADA 1980.)
}

\author{
Jakov JELINČIĆ \\ Pazin, Istarskih narodnjaka 18 \\ jakov.jelincic@gmail.com
}

\author{
UDK 27-9(497.571-027.541)(047.32) \\ Pregledni rad \\ DOI https://doi.org/10.31726/via.25.4
}

\begin{abstract}
Crkveni su arhivi bogat i nenadomjestiv izvor za proučavanje lokalne povijesti, posebno u slučajevima kada je arhivima nastalim djelovanjem državnih i inih civilnih organa vlasti gradivo spletom raznih okolnosti bilo uništeno. Godine 1970. dogovorom između Historijskoga arhiva u Pazinu (danas: Državni arhiv u Pazinu - DAPA) i Porečke i Pulske biskupije i Pazinske apostolske administrature započelo je popisivanje svih crkvenih arhiva na području navedenih crkvenih organizacija. Dvojica su djelatnika, jedan postavljen s crkvene strane, a drugi sa strane Arhiva, u vrijeme sređivanja i popisivanja navedenih crkvenih arhiva vodili Dnevnik koji je predmet ovoga rada. Dnevnik je prepisan sa svim pogreškama i osobitostima. Autor je priredio i »Kazalo« sjedišta u kojima su se u vrijeme toga rada nalazili crkveni arhivski fondovi, s naznakom dana kada je fond bio u obradi, sati utrošenih u sređivanju i popisivanju, rednoga broja pojedinoga mjesta i stranice Dnevnika. Zaključak je ovoga rada napisao mr. sc. Ilija Jakovljević.
\end{abstract}

Ključne riječi: Porečka i Pulska biskupija, Pazinska apostolska administratura, crkveni arhivi, Dnevnik rada, popisivanje arhivskoga gradiva

Keywords: Diocese of Poreč and Pula, Pazin Apostolic Administration, church archives, Logbook, listing of archives

Parole chiave: Diocesi di Parenzo e Pola, Amministrazione apostolica di Pisino, archivi ecclesiastici, Registro di lavoro, registrazione di materiale archivistico

\section{UVOD}

Odluka blagopokojnoga porečkog i pulskog biskupa Dragutina Nežića da na tromjesečni tečaj za arhivske djelatnike u Zagrebu pošalje svećenika Ivana Graha, tada župnika u Gračišću, bila je providonosna za arhivsku službu Crkve u Istri. Nežić se i sam bavio poviješću i istraživanjem primarnih povijesnih izvora i odmah je shvatio opravdanost pri- 
jedloga direktora Arhiva Hrvatske Bernarda Stullija da biskupije i crkveni redovi pošalju na tečaj svoje predstavnike, s obzirom na vrijednost arhivskoga gradiva što ga Crkva posjeduje. Poznajući dobro obojicu i s njima surađujući, moram reći da sam bio zadivljen njihovom suradnjom i prijateljstvom iako su bili posve suprotnih pogleda na svijet. Povezivala ih je ljubav prema povijesti i povijesnim izvorima. Nežić vjerojatno nije dugo dvojio koga poslati jer je poznavao Grahovu sklonost prema proučavanju crkvene povijesti i povijesti uopće, što je bez arhivskih dokumenata zapravo nemoguće. Na kraju dopisa poslanoga Grahu biskup navodi: »Nadamo se, da ćete Vi tromjesečni studij arhivistike pohvalno svladati, što će biti na veliku korist i čast Crkve u Istri.«

Ivan Grah »rođen je u Cerovlju 17. ožujka 1928. od oca Josipa i majke Ane, rođene Rade. Školske godine 1945/1946. dolazi iz koparskog u pazinsko sjemenište i ondje je maturirao 21. lipnja 1948. godine. Teološki studij pohađa u Rijeci i Zagrebu. Zaređen je za svećenika 7. srpnja 1952. u Cerovlju. Kao župnik djelovao je najduže u Gračišću od 1952. do 1983. godine, odakle je do umirovljenja 2009. bio župnikom Ližnjana i Šišana. Preminuo je 23. travnja 2011. u Puli.« ${ }^{1}$

Velečasni Grah bio je jedan od najmarljivijih polaznika tečaja, koji je trajao od 5. rujna do 5. prosinca 1968. Ispit smo polagali od 15. do 22. prosinca iste godine. Koliko se sjećam, ispit je položio odličnim uspjehom. Također naglašavam da se ispit mogao polagati u dva dijela, a da je Grah, za razliku od nas većine, ispit polagao odjednom.

Dolaskom profesora Dražena Vlahova na mjesto direktora pazinskoga arhiva u rujnu 1970., počela je suradnja između Arhiva i Ordinarijata. Vlahov je predložio biskupu da se popišu crkveni arhivi Porečke i Pulske biskupije i Pazinske apostolske administrature. Biskup je to objeručke prihvatio te je dekretom imenovao velečasnoga Graha, a Vlahov arhivista Jakova Jelinčića.

Bilo je i drugih svećenika i redovnika koji su pohađali tečaj, ali mi nije poznato da je još u kojoj (nad)biskupiji ili redovničkoj provinciji na taj način popisano crkveno gradivo. U tom smislu treba odati posebno priznanje biskupu Nežiću, Bernardu Stulliju, velečasnom Grahu te prof. Draženu Vlahovu.

Za konačnih 500-tinjak stranica inventara: kaptolskih, dekanatskih, župnih i kapelanijskih arhiva koji su nastali radom Ivana Graha i moje malenkosti, rekao je svjetski priznati stručnjak Bernard Stulli da su »zlata vrijedni«. Ipak, ne smatram da su savršeni. Arhivska služba napreduje pa neka budući djelatnici naprave bolje ako smatraju da je to potrebno.

Treba reći da je Državni arhiv u Osijeku (ranije Historijski, odnosno Povijesni arhiv u Osijeku) također pokazao veliku brigu za crkvene i općenito arhive vjerskih ustanova, a rezultat akcija iz kraja šezdesetih, početka sedamdesetih, osamdesetih godina te krajem devedesetih godina 20. stoljeća i početkom 21. stoljeća jesu dosjei stvaratelja / imatelja vjerskih zajednica na području nadležnosti navedenoga arhiva. ${ }^{2}$

1 Elvis ORBANIĆ, »Mons. Ivan Grah, crkveni arhivist i povjesničar: bibliografija«, Arhivski vjesnik, 55, Zagreb, 2012., str. 73-86.

2 Detaljnije o tom vidi u: Dražen KUŠEN, Arhivi vjerskih zajednica u Sjevernoj Hrvatskoj. Razvoj, tipologija, Sadržajni značaj, Doktorska disertacija, Filozofski fakultet Sveučilišta u Zagrebu, Zagreb, 2011., 
I drugi državni arhivi vode evidencije o gradivu crkvenih / vjerskih arhiva u okviru svoje teritorijalne nadležnosti.

Tekst Dnevnika svojevrstan je vremeplov rada dvojice zaljubljenika u crkveno arhivsko gradivo. Kao dugogodišnji prijatelj i suradnik pokojnoga monsinjora Ivana Graha, čitajući pozorno ovaj Dnevnik, moram s divljenjem reći da je Dnevnik, ponajviše zahvaljujući upravo njemu, ogledalo jednoga rada i jednoga vremena. Ljudi poput Ivana Graha, usuđujem se reći, rađaju se jednom u stotinu godina, vjerojatno ni u toliko. Bio je to čovjek velikih intelektualnih, ali i radnih sposobnosti, koji je mogao bez problema raditi i po četrnaest i više sati dnevno. U isto vrijeme bio je vrstan pastoralac, svećenik i župnik. Kao povjesničar držao se samo istine, pa i onda kada je ta istina mnogima smetala. Ponosan sam što sam bio njegov prijatelj i suradnik i što sam mogao biti suautorom ovoga Dnevnika. Neka mi stoga bude dopušteno ovaj rad posvetiti upravo blagopokojnom monsinjoru Ivanu Grahu koji je napisao najveći dio Dnevnika, kao trajni spomen na skromna čovjeka koji je obilježio dio povijesti istarske Crkve.

Na kraju navodim sljedeće: kao što je uobičajeno, a od Uredništva Vjesnika istarskog arhiva i sadašnjega ravnatelja prihvaćeno, tekst sam Dnevnika prepisao sa svim pravopisnim i ostalim jezičnim pogreškama i osobitostima. Dio je njih posljedica pisanja Dnevni$k a$ u kasnim večernjim satima.

\section{DNEVNIK RADA}

Ivan Grah, župnik Gračišća

Jakov Jelinčić, prof., arhivist Historijskog arhiva Pazin

Plan sređivanja arhivske građe ${ }^{3}$

\section{A. Knjige}

1.1 dalje Knjige cirkulara, više naredbe, dopisi

2.1. “ Urudžbeni zapisnici, protokol

3.1. " Matične knjige krštenih

4,1 " “ " $\quad$ vjenčanih (Fol. dioec. 1940., str. 157)

5,1 " " " " umrlih

6,1 " " "

7,1 “ Stanje duša (status animarum)

8,1 “ Računske knjige, blagajnički dnevnici, glavne knjige, pomoćne knj. (ponekad i odvojene (8,1 - i 9,1 -) ako ih ima mnogo)

str. $62-76$.

3 Ovaj se tekst nalazi na početku knjižice, bez naznake stranice, a sam je tekst Dnevnika označen stranicama od 1 do 68 , dok str. 69 i 70 nisu označene. 
9,1 “ Razne knjige, fundacije, katazen (? $)^{4}$, oglasi, napovijedi, obavijesti, prima nota itd., kronike, inventari

B. Spisi

10,1 Službeni spisi, opći spisi, župni spisi - u manjim župama zajedno

11,1 Ženidbeni spisi

12,1 Razni spisi

ili $13,1 \quad$ Sudski spisi

14,1 Ugovori ili kontrakti ako su odvojeni.

15,1 Razni spisi

NB.Raznih spisa, a i knjiga mora biti što manje. Stoga je uputno da se u većim župama izvrši detaljnija podijela pod posebnim matičnim brojem. (I. G.)

(Slijedi prazna stranica.)

\section{GODINA}

Ivan Grah, župnik Gračišća

Jakov Jelinčić, prof., arhivist Historijskog arhiva Pazin

(str. 1)

1. Gračišće, $18.12 .1970 .^{5}$

Dne 18. XII 1970. radili smo na inventarizaciji arhivske građe u župi Gračišće. Radom smo započeli u 9 sati i završili u 17. Kroz to vrijeme izvršili smo popis svih knjiga koje spadaju u župni arhiv od najstarijih do 1945 . godine. Ukupno 40 raznih knjiga. (I. G. ${ }^{6}$

Ivan Grah Jakov Jelinčić

2. Gračišće, 22. 12. 1970.

Dne 22. XII. 1970. radili smo na identificiranju i odvajanju raznih spisa na godine. Jedan svežanj smo sredili po godinama, zatim odvojili računske spise, oporuke, legate i drugo (2 svežnja). Ukupno: 2 svežnja identificirana i jedan svežanj sređen. Rad započet $\mathrm{u}$ 830 , a završen u 1530. (J. J.)

Ivan Grah Jakov Jelinčić

\footnotetext{
$4 \quad$ Riječ nejasno napisana. (J. J.)

5 Župnik Ivan Grah. (J. J.)

6 U zagradama navodim tko je sastavio zapisnik. (J. J.)
} 


\section{GODINA}

\section{Gračišće, 8.1.1971.}

Dana 8.1.1971. radili smo na identificiranju građe pod oznakom VARIA (jedan svežanj) i na kontroliranju sređenosti sačuvane građe. Ustanovljeno je da je sređena slijedeća građa: računi (conti) i ženidbeni spisi. Opći spisi uglavnom su također sređeni i to kronološkim redom (spise pod: RAZNO) treba srediti, a granične godine su približno utvrđene. Zatim je izvršeno numeriranje i napisan je inventar za ukupno 31 svežanj. S radom smo započeli u 9 sati, a za- (str. 2) vršili ga u 14 s. Nakon toga otišli smo u Pićan radi priprema radova na popisu arhive u tom župskom uredu. (J. J.)

Ivan Grah Jakov Jelinčić

4. Pićan, dne 15. veljače 1971.

Danas smo radili na identificiranju arhivske građe u ovom župnom arhivu. Tokom rada nailazili smo na strukturalne poteškoće pošto se zajedno nalaze knjige i spisi koji u stvari spadaju u tri različita fonda tj. biskupijski, dekanatski i župski. Uspjeli smo donekle kronološki poredati knjige protokola, a ostale po predmetu. Od spisa, koji su pretežno sređeni kronološki po godištima i predmetno identificirali smo seriju dekanatskih spisa i nekoliko svežnjeva „razno“ koji spadaju u župske spise. Radom smo započeli u 9s i prekinuli u 15. U radu su pomogli domaći župnik i sakristan ${ }^{8}$. (I. G.)

Ivan Grah Jakov Jelinčić

5. Pićan, 16. veljača $1971 .{ }^{9}$

Radom smo nastavili u 7 s. i prekinuli u 15. Danas smo uglavnom kronološki poredali opće dekanatske spise tj. svežnjeve, neke smo letimično i pregledali i ustanovili da su jedinice poredane i numerirane kao i to da po neke (!) jedinice fale. Odijelili smo matrimonijalne svežnjeve spisa i sve spremili za popisivanje. Pri koncu rada najšli (!) smo na par svežnjeva biskupijskih spisa koji mogu spadati u rara i rarissima ${ }^{10}$ : naišli smo na kronološki popis pićanskih biskupa kao i na prijepis Urbara Pićanske biskupije iz $1722 .{ }^{11}$ Izgleda da je na pomolu i četvrti fond (str. 3) pomješan u istom arhivu: radi se o spisima kaptolskog arhiva. (I. G.)

Ivan Grah Jakov Jelinčić

Župnik Ivan Štoković. (J. J.)

$8 \quad$ Sakristan Pino Kiković. (J. J.)

9 U izvorniku je ovaj naslov zajedno s tekstom izvješća. Kako bismo ga ujednačili s ostalim dijelom Dnevnika, izvješće smo odvojili. (J. J.)

10 Rijetki i vrlo rijetki (spisi). (J. J.)

11 Ivan GRAH ga je objavio u Vjesniku historijskih arhiva u Rijeci i Pazinu (VHARIP), pod naslovom »Urbar Pićanske biskupije (1617-1621)«, VHARIP, sv. XVI, Rijeka, 1971., str. 263-283. (J. J.) 
6. Pićan, dne 25. veljače 1971.

Radom smo započeli u $8^{\mathrm{s}}$ i uz mali predah radili do $17^{30}$. Poredali smo i spremili za popisivanje svežnjeva spisa: ženidbene spise, opće spise, spise o školama na području dekanata i računske spise. Tokom rada smo ustanovili da su neki svežnjevi sređeni, neki polusređeni, a neki ni predmetno i vremenski sređeni. (I. G.)

Ivan Grah

Jakov Jelinčić

7. Pićan, dne 26.2.1971.

Danas smo završili odvojiti posljednje svežnjeve spisa, poredali smo ih po predmetu i vremenski. Zatim smo prešli na popisivanje građe. Popisali smo sve knjige dekanatske i župske, a od spisa - računske, oporuke, ugovore, inventare, župni beneficij i štampane stvari. Radom smo započeli u $7^{\mathrm{s}}$ i završili u $17^{30}$. (I. G.)

Ivan Grah

Jakov Jelinčić

\section{Pićan, dne 1.3.1971.}

Danas smo uglavnom završili s popisom građe, sastavili inventar, svežnjeve poredali u ormare, knjige također. Preostalo je za (!) popisivanje serija „Razno“, što će biti naknadno izvršeno. Danas su nas posjetili direktor (str. 4) Arhiva Vlahov Dražen i referent za vanjsku službu Leuštek Josip. Radom smo započeli: Jakov Jelinčić u $7^{\text {s }}$, a Ivan Grah u 9 i završili u 16 sati. (I. G.)

Ivan Grah Jakov Jelinčić

\section{Lindar, 26.3.1971. ${ }^{12}$}

Danas smo sređivali arhivu župe Lindar. Građa je relativno sređena. Posebno dobro su sačuvani dekreti (1794-1902.). Izvršen je popis: 48 knjiga i 33 svežnja spisa. Ivan Grah započeo je s radom u $8^{30}$, a Jelinčić u 9 sati. Posao je završen u $17^{30}$ sati. (J. J.)

Ivan Grah Jakov Jelinčić

10. Gologorica, 15.4.1971.

Danas smo sređivali arhivu župe Gologorice. Građa je sređena, pa je radi toga relativno mnogo posla. Izvršen je popis: 45 knjiga (razvrstane su u 10 grupa) te 73 svežnjića spisa. Posebno je interesantna župska kronika. I inače treba naglasiti da je kancelarija dobro vođena posebno za župnikovanja Ljudevita Zvačeka koji je bio rodom iz Moravske. Radom smo započeli u $9^{30}$, i s pauzom od 1 sata radili do 17 sati. (J. J.)

Ivan Grah Jakov Jelinčić

12 Župnik lindarski Ivan Bartolić. (J. J.) 
(str. 5) 10a ${ }^{13}$ Cerovlje, 15.4.1971.

Od $17^{30}$ do $18^{30}$ sredili smo arhivu župe Cerovlje, kapel. Borut i crkve Previž, te mali dio arhive župe Novaki (Pazinski) koji se nalazi u Cerovlju, jer ovdašnji upravitelj župe upravlja i Novakima. (J. J.)

Ivan Grah

Jakov Jelinčić

\section{Pazin - sjemenište, 22.IV 1971. od 8 do 15 sati.}

U sjemeništu, u predsoblju Biskupske kancelarije nalaze se privremeno pohranjeni arhivi župe Pazinski Novaki i Barbana. Danas smo uglavnom sređivali svaki po jedan fond: Jakov Jelinčić Barbanski, a ja Ivan Grah Novački ${ }^{14}$. I jedan i drugi fond iziskuju mnogo truda da se srede za inventariziranje. Novački je fond poprilično složen, kompliciran i pomiješan s fondom kapelanijskih ureda Borut i Zarečje kao i župe Cerovlje. Barbanski fond oko $70 \%$ građa je nesređena a pripada većim dijelom Kaptolskom arhivu. (I. G.)

Ivan Grah Jakov Jelinčić

12. Pazin - sjemenište, 27.IV od $8^{30}$ do 15 sati.

Kao gore. Danas je građa uglavnom raspoređena po vrstama tako da će se idući put moći početi sa popisivanjem. (J. J.)

Jakov Jelinčić

Produžio rad do $17^{30}$.

Ivan Grah

(str. 6) 13. Pazin, sjemenište, dne 30.IV.1971.

Današnji sam dan dovršio dijeljenje fondova na župni ured Novaki, Cerovlje zajedno s Previžem, i na kapelanijski ured Zareč ${ }^{15}$ i Borut. Najbogatiji je fond Pazinski Novaki koji ima lijepe i korisne građe za nauku. Najsiromašniji je fond Cerovlje. Prije popisivanja trebat će fondove kompletirati jer se dio građe nalazi u Cerovlju, Novakima i Zareču. Treba istaknuti činjenicu da fondovi nisu podijeljeni - detaljno je to gotovo nemoguće.

Jelinčić Jakov je nastavio sa sređivanjem Barbanskog fonda pošto mu je gosp. biskup dovezao još 10 metara barem (! - J. J.) građe koja pripada istom fondu. Radom započeli u $8^{30}$ sati i završili u 14 sati. (I. G.)

Ivan Grah

Jakov Jelinčić

13 U Dnevniku nema rednoga broja. Za potrebe objavljivanja dodan je br. 10a. (J. J.)

14 Radi lakšega razumijevanja vjerojatno bi trebalo stajati novačanski, no s obzirom da se Dnevnik objavljuje ad literam, ostavio sam ga onako kako stoji u njemu, a iz samoga je izvješća o radu razvidno o kojem se fondu radi. (J. J.)

15 Ivan Grah u pojedinim slučajevima umjesto Zarečje piše Zareč. (J. J.) 
14. Pazin, sjemenišste, 7. svibnja 1971.

Radio samo Jakov Jelinčić i nastavio s poslom već gore opisanim od 7 do 15 sati. (J. J.)

Jakov Jelinčić

15. Pazin, sjemenišste, 22.6.1971.

Radili su Ivan Grah i Jakov Jelinčić. Ivan Grah je sortirao knjige, a Jelinčić spise pripremivši ih tako za konačno popisivanje.

Rad je trajao: Grah od $8^{30}$ do 18 sati, a Jelinčić od 7 do 15 sati. (J. J.)

Ivan Grah Jakov Jelinčić

(str. 7) 16. Sjemenište (Pazin), 23.6.1971.

Od 7 do 13 sati radili su Jakov Jelinčić i Gracijela Paulović16. Oni su knjige i svežnjeve numerirali, popisali i postavili na police i u ormar. (J. J.)

Jakov Jelinčić

Isti dan obišao tvorce fondova: Zareč, Pazinski Novaki, Cerovlje i Borut građa se kojih djelomično nalazila $u$ rasutom stanju u sjemeništu na dogovor za preuzimanje građe $i$ kompletiranje fondova. Vrijeme 8 do 12 sati. Popodne otišao na dogovor za uređenje građe u župama Krbune i Tupljak. (I. G.)

Ivan Grah

\section{Pazin, župni stan, 7. X. 1971.}

Danas smo započeli radom na sređivanju fondova kod ovoga tvorca građe. Najprije smo odvojili knjige od spisa, zatim se prof. Jelinčić posvetio knjigama, a Ivan Grah spisima. Prvi je podijelio knjige na župni i dekanatski fond i počeo popisivati knjige protokola, okružnica i urudžbene zapisnike oko 40 komada. Drugi je učinio isto sa spisima i uspio popisati 40 svežnjeva ženidbenih i kronološki poredati preko 80 dekanatsko-župnih spisa. Radom smo započeli u $8^{30}$ i radili do 12 sati. Između 14 i 15 sati Ivan Grah prevezao građu kapelanskoga fonda Zarečje iz sjemeništa gdje je bila privremeno deponirana u samo sjedište njezinoga tvorca. Isto učinio za Cerovlje. (I. G.)

Ivan Grah Jakov Jelinčić

(str. 8) 18. Pazin, 8.X.1971.

Nastavak daljnjeg sređivanja i popisivanja: prof. Jakov Jelinčić završio s popisivanjem knjiga krštenih, krizmanih, vjenčanih, umrlih, raznih i računskih (oko 60 komada), Ivan Grah radio opće spise, odvojio razne od školskih, župskih i sudskih (oko 150 svežnjeva). Radom smo započeli u 9'. Ivan Grah prekinuo u 14, a Jakov Jelinčić u 15. (I. G.)

16 Gracijela Paulović, arhivski pomoćnik u Historijskom arhivu u Pazinu. (J. J.) 


\section{Pazin, 11.X.1971.}

Danas smo zajedno radili na popisivanju dekanatsko-župnih spisa (86 svežnjeva), školskih (30 svežnjeva). Ujedno smo morali kompletirati neke svežnjeve. Radom smo započeli

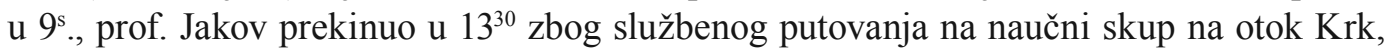
a Ivan Grah nastavio radom sve do 17 sati. Popodne je pomogao u radu g. župnik - dekan Ivan Bartolić. Treba napomenuti da je arhivsku građu počeo proučavati i sređivati raniji župnik - dekan mons. Leopold Jurca, nastavio današnji uz pomoć č.č. sestara. Međutim građu nisu poredali ni po fondovima ni po predmetima. Prigodom toga rada osakatili su fondove time što su "važnije" spise vadili iz svežnjeva i uredili neku zbirku koju su smjestili u posebni ormar u župnom uredu. Arhivistički je takav rad nedozvoljen. Mi smo to ostavili status quo smo zatekli (!) i uveli zbirku razno od br. 12,8 dalje.

Ivan Grah Jakov Jelinčić

(str. 9) 20. Pazin, dne 15. X.1971.

Radio od $13 .{ }^{30}$ do 19 sati sam Ivan Grah i popisao sudske spise (2 sv.), računske (12 sv.), župske (2 sv.), donekle poredao razne (20) koji obuhvaćaju vrijeme od XVI stoljeća do 1934. (I. G.)

Ivan Grah

21. Obišli slijedeće župske arhive: Vodnjan, Bale, Rovinj - župa, Rovinj - samostan, Novigrad, Umag, Buje i Oprtalj. Arhivska građa u Vodnjanu sređena i katalogizirana, pergamene su u dobrom stanju. U Balama arhiv je nesređen, uzeli smo tri pergamene $\mathrm{i}$ dva papira za restauriranje. U Novigradu vidjeli smo svega nekoliko pergamena, koje su uokvirene i stalno izložene, zato je tinta izblijedila i predložili smo da se naprave zavjesice za zaštitu pergamena. Arhiv je nesređen i zbog pomanjkanja nužnog prostora. U Umagu arhiv je sređen i invetariziran, našli smo za restauriranje jednu pergamenu i jednu topografsku kartu. U Oprtlju arhiv je uglavnom sređen. Prevalili smo preko 200 km: otišli smo iz Pazina u 9 sati i vratili se u 23, dana 21. listopada 1971. (I. G.)

Jakov Jelinčić

Ivan Grah 
22. Cerovlje-Zarečje, 22. X.1971.

Danas sam popisao građu u ta dva fonda: građa je bila prije sređena i dopremljena tvorcima. Međutim mnogo je građe pomiješano s onom iz Paz. Novaki, jer je i sudbina Novaki, Zarečja, Cerovlja i Boruta tijesno povezana i građa srašćena gotovo u jednu cjelinu. Radio 2 sata. (I. G.)

Ivan Grah

(str. 10) 23. Rovinj, 25.10.1971.

Započeo sa osnovnim sređivanjem građe župskog arhiva u Rovinju, a zatim započeo sa klasiranjem knjiga. Sa radom sam započeo u $8^{45}$ sati, a završio, uz prekid za ručak, u 18 sati. (J. J.)

Jakov Jelinčić

\section{Rovinj, 26.10.1971.}

Nastavili sa sređivanjem (grubim) spisâ. Treba naglasiti da je fond samo djelomično sređen i ujedno da je najveći koji smo do sada obrađivali. No, srećom, sakristija je velika, pa to olakšava posao. Sa radom smo započeli u $10^{30}$ sati, a završili, uz prekid za ručak, u 19 sati. (J. J.)

Ivan Grah

Jakov Jelinčić

25. Rovinj, 27.10.1971.

Jakov Jelinčić nastavio sa sređivanjem knjiga i započeo s popisivanjem istih. Radom započeo u $7^{30}$ i prekinuo radom u $18^{\mathrm{s}}$ uz kratku pauzu u $13^{\mathrm{s}}$. Ivan Grah se dalje bavio sređivanjem i diobom spisa na fondove i predmete. Današnji je posao bio otežan činjenicom što je građa u rasutom stanju. Radio od 11 do 18 sati. (I. G.)

Ivan Grah

P. S. U $12^{45}$ posjetili su nas sekretar općine i referent za kulturu. (J. J.)

Jakov Jelinčić

(str. 11) 26. Rovinj, 29.10.'71.

Počeo sam sa grubim popisivanjem knjiga te popisao sljedeće grupe knjiga: zapisnike kaptolskih vijeća, vachette ${ }^{17}$, status animarum, popise stanovnika te matične knjige svih vrsta. Radio sam od 8 do 14 sati. (J. J.)

\section{Jakov Jelinčić}

17 Imenicu vacheta i vaceta nalazimo u talijanskim i latinskim rječnicima, prvu kao vrstu broda, a drugu kao vrstu tkanine. U ovom je smislu nalazimo jedino u rječniku Gianni PINGUENTINI, Nuovo dizionario del dialetto triestino Storico Etimologico Fraseologico, kao računsku knjižicu (VACHETA - termine marinaresc, libriccino nel quale lo scrivano, ora primo ufficiale, registrava i conti individuali dell'equipaggio (anticipi, competenze straordinarie, ecc.); era così chiamato pure il brogliaccio dei mercanti e pubblici ufficiali, da segnarvi provisoriamente le partite da trascrivere poi sui registri (provizorna 


\section{Rovinj, 3.11.'71.}

Nastavili smo sa sređivanjem građe. Ivan Grah sređivao je spise (odjeljivao računske, opće i ženidbene), a Jakov Jelinčić nastavio sa grubim popisivanjem knjiga. Ostale su još za popisivanje knjige razne i dio računskih knjiga te knjige bratovština. Radili od $9^{30}$ do $18^{15}$ (prekid ručak). (J. J.)

Ivan Grah Jakov Jelinčić

\section{Rovinj, 5.11.'71.}

Nastavili smo sa sređivanjem građe. Jakov je nastavio i dovršio s grubim popisivanjem, a Ivan Grah odvajao spise: ženidbene, opće i računske. Započeli sa radom u od $9^{30}$ a završili u 19 sati. (J. J.)

Ivan Grah

Jakov Jelinčić

(str. 12) 29. Rovinj, 6.11.1971.

Započeo sam sa konačnim popisom građe (knjiga) i to: knjige prepoziture, matične knjige i sve knjige Kaptola. Radio od 7 sati do $20^{30}$ s. (J. J.)

Jakov Jelinčić

\section{Rovinj, 8.XI.1971.}

Danas sam započeo raditi u $10^{30}$ i uz malu pauzu nastavio do 19 sati. Pomogao mi je jedan mladić iz Gračišća. Sredili smo i popisali župne spise (39 svežnjeva) i ženidbene (69 svežnjeva). (I. G.)

Ivan Grah

\section{Rovinj 12.XI.1971.}

Radom započeli obojica u $9^{30}$ i nastavili do $19^{30}$. Prof. Jakov bavio se popisivanjem knjiga, a Ivan Grah popisivanjem računskih spisa (37 svežnjeva) sudskih, zakladnih i pomoćnih. (I. G.)

Ivan Grah Jakov Jelinčić

\section{Rovinj 15.XI.1971.}

Danas je konačno prof. Jelinčić uz pomoć Leuštek Josipa ${ }^{18}$ dovršio s popisivanjem knjiga i kaptolskih spisa i spremio ih u ormar. Tokom rada bilo je pronađeno još 10 svežnjeva

knjižica iz koje se kasnije prepisivalo u čisto - J. J.) ... deriva il nome dalla rilegatura in pelle vaccina conciata (vachetta) /nazvana prema uvezu u štavljenu kravlju kožu/, Cappelli editore, Treviso, 1969., str. 343.

18 Josip Leuštek, voditelj Vanjske službe Historijskoga arhiva u Pazinu. 
općih spisa koje je Ivan Grah sredio i popisao i zatim pomogao u sređivanju kaptolskih spisa. Radom započeli u 11s i završili u 21. (I. G.)

Ivan Grah Jakov Jelinčić Josip Leuštek

(str. 13) 33. Rovinj, 23.XI.1971.

Danas sam uspio iz hrpe nesređene građe dekanatskog arhiva u Rovinju srediti i popisati 33 svežnja. Radom sam započeo u $11^{\mathrm{s}}$ i završio u 19. Nekoliko mi je sati pomagao novoimenovani dekan Milovan Ivan ${ }^{19}$. (I. G.)

Ivan Grah

\section{Tupljak, 26.XI.1971.}

Danas sam autom prevezao arhivsku građu iz napuštenog župnog ureda u Krbunama u novi župni ured Tupljak. Zatim sam pristupio sređivanju iste po fondovima. Građa je manjkava do oko 1850. godine. Najvrijednija je svakako matična knjiga iz 1698 do 1769. Knjiga je bila restaurirana 1940. godine i sačuvan je stari uvez presvučen pergamenom staroslavenskog misala koje stoljeće starijega. Popisao sam preostale knjige župe Krbune i podružnice Tupljačke i Grobnika, zatim 14 župskih (!) spisa, 7 sudbenih, 18 računskih i 5 raznih $^{20}$. U radu je pomogao mladi upravitelj župe Zović Josip. Radom započeli u $13^{\mathrm{s}}$ i završili u 21. (I. G.)

Ivan Grah

\section{GODINA}

(str. 14) 35. Trviž, 21.2.1972.

Danas smo sortirali, već složenu arhivsku građu, po predmetima, a unutar predmeta kronološki, zatim smo prešli na popisivanje razne građe. Knjige smo uveli pod mat. brojeve od 1 do 7. Treba istaknuti da nam ovaj arhiv nije dao mnogo muke zahvaljujući ranijem župniku ${ }^{21}$ koji je arhivsku građu lijepo uredio i svako godište spremio u posebnu zaštitnu košuljicu. Radom smo započeli u $9^{\text {s }}$ i završili oko 14 sati. U radu je pomogao i domaći župnik Mirko Štoković. Posjetili smo zatim župni arhiv u Mot. Novakima koji je u rasutom stanju. (I. G.)

Ivan Grah Jakov Jelinčić $\quad$ Mirko Štoković župnik

19 Kasniji porečki i pulski biskup.

20 Radi se o svežnjevima. (J. J.)

${ }^{21}$ Radi se o Leopoldu Jurci (1929. - 1945.). (J. J.) 
36. Stari Pazin, 22.2.1972.

Obavivši posao u Trvižu i pregled u Motovunskim Novakima otišli smo u Stari Pazin (21.2.) da pogledamo u kakvom je stanju sređenosti građa i kolika je njena količina. Pregledavši ga dogovorili smo se sa župnikom da ćemo idućeg dana doći k njemu.

22.2. smo započeli sa radom u 9 sati, a završili u $13^{30}$. U radu nam je pomogao domaći župnik Ante Merlić. Građa je bila sređena po godinama, a osim toga i nema je mnogo pa je posao zato završen relativno brzo. Knjige smo zaveli pod matičnim brojevima od 1 do 9 , (str. 15) a spise od 10 do 13 (knjiga 40 kom, a spisa 31 svežanj) (J. J.)

Jakov Jelinčić

P. s. Jedan svežanj dekanatske građe pronađen i ubačen u dekanatski fond u Pazinu.

Ivan Grah

\section{7. Čepić, kod Kršana, ${ }^{22} 23.2 .1972$.}

Sređivanje i popisivanje ove građe nije bilo planirano za ovu godinu. Na molbu tamošnjeg župnika Milana Milovana popisao sam građu. Radio sam od 16 do $20^{45}$ sati. Građa je bila djelomično (većim dijelom) sređena. Knjige sam popisao pod matičnim brojevima 1 do 3, a spise od 4 do 8 (knjige: 13 kom., spisi: 41 svežanj) (J. J.)

Jakov Jelinčić

\section{Rovinj, 23.2.1972.}

Danas po podne složili smo arhivsku građu župe i dekanata Rovinj u nove regale, koje je župi darovala Općina Rovinj. U radu su pomagali župnik ${ }^{23}$, kapelan ${ }^{24}$ i jedna časna sestra. Kao posljednje uspio sam donekle poredati raznu nesređenu građu i uveo je pod „razno“ u 8 svežnjeva. Utrošili smo oko 10 sati zajedničkog rada. (I. G.)

Ivan Grah

39. Tinjan, 7.3.1972. od 9 do 13 sati.

Danas po podne sredili smo arhivsku građu u župi Tinjan (7 - 8 metara građe). U raniji poredak i plan sređivanja građe nismo dirali. Knjige uvedene pod matične brojeve od 1 do 8, a spisi od 9 do 12. U radu je pomogao župnik. (I. G.)
Jakov Jelinčić
Ivan Macinić
Ivan Grah

\footnotetext{
22 Postoji, naime, i Čepić (negdje: Čepići) kod Oprtlja, koji je dio župe Šterna. (Vidi: Marijan BARTOLIĆ - Ivan GRAH (ur.) i suradnici, Crkva u Istri, III. dopunjeno izdanje (stanje 1. lipnja 1998.), IKD »Juraj Dobrila«, Pazin, 1999., str. 154.) (J. J.)

23 Župnik Miroslav Milovan (1965. - 1981.).

24 Kapelan, točnije, pastoralni suradnik Ivan Milovan, kasnije rovinjski župnik i porečki i pulski biskup. (J. J.)
} 
(str. 16) 40. Beram, 8.3.1972.

Danas sam kroz 6 sati neprekidnog rada uspio složiti po predmetu i popisati arhivsku građu župnog fonda u Bermu. Između dvadesetak knjiga najviše su matice krštenih (2,1 i $2,2)$ koje su se počele voditi 1689. godine te zbog svoje trošnosti vape za restauriranjem. Svih spisa ima četrdesetak svežnjeva podijeljenih u četiri grupe. Važni su proučavanje (!) agrarni spisi. Naišao sam na tipičan pojam „,volarina“ ili „manzonaria“, naziv koji je označavao naturalna primanja župnika: vjerojatno je to bilo staro urbarijalno pravo župnika kao ,plebanus-a castri“ kome su davali svoje obveze seljaci prema broju volova. U radu mi je pomogao i upravitelj župe, koji ekskurira ${ }^{25}$ iz Tinjana. (I. G.)

Ivan Grah

\section{Cere (Sveti Matej) i Sveti Ivanac nad Rašom, 9.3.1972.}

Danas smo s lakoćom izvršili popis arhivske građe ovih fondova koje je domaći župnik Širol Romano pedantno sredio po predmetu i kronološki, te svaku jedinicu spremio u zaštitnu košuljicu, a svežnjeve u zaštitne kartone. U radu je postupio po svim arhivističkim propisima i pravilima do kojih je došao radom i slušanjem seminara iz tog predmeta koji je bio organiziran za istarski kler u Pazinskom sjemeništu 1971. godine. Građa obaju fondova zaprima dvadesetak svežnjeva i dvadesetak knjiga. Radom smo započeli u $10^{30} \mathrm{i}$ završili u 13 sati. (I. G.)

$$
\text { Jakov Jelinčić }
$$$$
\text { Romano Širol }
$$

Ivan Grah

\section{(str. 17) 42. Žminj, 9.3.1972.}

Građa ovog fonda nije nam zadala naročite poteškoće jer ju je dobro sredio župnik Krebel Marcel. Treba napomenuti da je građa ovoga fonda u većem dijelu propala kad je bio uništen do temelja župni stan za vrijeme bombardiranja Žminja sa strane njemačkih aviona 1943. godine. Iz ruševina je župnik Glavić uspio spasiti barem matične i druge knjige, dok je drugo sve propalo. Spašene je knjige isti župnik dobro sakrio a da mjesto nije otkrio nikome. ${ }^{26}$ Dragocjen je nalaz bio otkriven tek 1957. godine: matične knjige datiraju od 1662, knjige bratovština od 1631. godine. Ima više knjiga s uvezom u pergamenu koje bi trebalo restaurirati. Radom započeli u 14 sati i radili: prof. Jelinčić do $16^{\text {s }}$, a Ivan Grah oko $18^{30}$ završio s inventarizacijom. Knjiga ima oko pedesetak, a svežnjeva spisa 17. (I. G.)

Jakov Jelinčić Ivan Grah

\section{Zamask i Kašćerga, 14.3.1972.}

Danas smo uspjeli srediti i popisati knjige i spise u ova dva fonda: u Zamasku smo popisali 30-tak knjiga i 21 svežanj spisa; u Kašćergi 40-ak knjiga i 31 svežanj spisa. U vrijedniju građu možemo ubrojiti matične knjige koje bi trebalo restaurirati i župnu kroni-

25 Ekskurirati u crkvenom smislu znači: upravljati drugom župom - izvan svoje župe. (J. J.)

26 Kasnije smo ipak utvrdili da je dio gradiva spašen. Vidjeti br. 119 i 120 od 9. i 10. 9. 1975., str. 51. (J. J.) 
ku Kašćerge od 1895. godine dalje. Radili uz pomoć domaćega župnika Kramar Ivana u Zamasku od $9^{30}$, a u Kašćergi od $12^{15}$ do $15^{30}$ sati. Građa obaju fondova čuva se u drvenim ormarima i jednoj drvenoj škrinji župnih ureda Zamaska i Kašćerge. (I. G.)

$$
\text { Jakov Jelinčić Ivan Grah }
$$

\section{(str. 18) 44. Kringa 12.IV 1972}

Danas sam uz pomoć domaćeg župnika Kalčić Josipa uspio složiti, podijeliti i popisati arhivski materijal ove župe. Treba napomenuti da je ovaj fond manjkav, jer je dio arhivalija bio uništen i spaljen kad su fašisti 1921. godine upali i premlatili župnika, domoroca Milanović Boža. Nagoreni su i oštećeni spisi zavedeni pod razno od broja 13,1 do 13,7, dok je ostala građa u dobrom stanju. Vrijedne su matične knjige koje datiraju od 1656. dalje. Novija građa tj. od 1917. dalje uglavnom službeni spisi nisu sređeni. Radom započeli u 8 sati i završili u 18 sati. (I. G.)

$$
\text { Ivan Grah }
$$

\section{Oprtalj, 3.V.1972.}

Danas smo sređivali i popisivali građu župskog i dekanatskog ureda u Oprtlju. Sa radom smo započeli u 9 sati, a završili u $19^{30}$ sati. Građa je većim dijelom sređena i dobro uščuvana. Matične knjige su pred par godina čvrsto uvezane. Posebno su dobro sačuvani i brojno vrlo dobro zastupljeni školski spisi. Građu smo podijelili po fondovima, zatim rasporedili i popisali po decimalnom sistemu. Osim toga posjetili smo Završje da bismo se upoznali sa građom koju moramo srediti i popisati. I tamo je, prema prvoj procjeni, građa dosta dobro sređena i dobro uščuvana, pa se (str. 19) nadamo da ćemo za jedan dan završiti posao. U radu nam je pomogao župnik Zvonimir Brumnić. (J. J.)

Jakov Jelinčić

Ivan Grah

\section{Završje, 24.5.1972.}

Danas smo sređivali i popisivali građu župskog ureda u Završju. Sa radom smo započeli u 9, a završili u 14 sati. Građa je dosta dobro sređena. Ima nekoliko vrlo vrijednih knjiga što je razumljivo kada se zna važnost feudalne jurisdikcije u Završju. (J. J.)

Ivan Grah

Jakov Jelinčić

\section{7. Šterna, 24.5.1972.}

Popodne u $15^{30}$ stigli smo u Šternu i nastavili sa radom. Sredili smo i popisali građu tog župskog ureda, koja je nažalost veoma manjkava no nešto je ipak sačuvano, a i dosta dobro sređeno. Sa radom smo završili oko $17^{15}$ sati. (J. J.)

Ivan Grah

Jakov Jelinčić 
48. Zrenj, 24.5.1972.

U 18 sati započeli smo sa sređivanjem i popisivanjem arh. građe župskog ureda u Zrenju. Arhive ima malo, djelomično je sređeno. Pri radu je pomogao domaći župnik Atilije Nefat. Sa radom završili u $20^{30}$ sati. (J. J.)

Ivan Grah Jakov Jelinčić

(str. 20) 49. Sv. Lovreč Pazenatički, 23.10.1972.

Danas smo izvršili popisivanje građe u ovom župnom uredu. Olakšavajuću okolnost u radu predstavljala je činjenica što je građa bila dosta dobro sređena. Građa je dobro sačuvana i restauracija nije potrebna. U radu nam je pomogao domaći župnik Marijan Jelenić. Sa radom smo započeli u 830 a završili u 17 sati. Nakon toga smo otišli u Poreč do biskupa da bismo mu predali mikrofilmove koje mu šalje Arhiv u Pazinu te da ga izvijestimo o stanju poslova na popisivanju.

Napomena: Popisali smo ukupno 71 svežanj spisa i 49 svezaka. (J. J.)

Ivan Grah

Jakov Jelinčić

Marijan Jelenić

50. Bale, 8.11.1972.

Izvršili smo grubo sređivanje građe u ovom župskom uredu. Pronađena je vrlo vrijedna građa: rovinjski statut (prijepis iz 1796.), prijepis raznih diploma, spisi o evakuircima u logoru Wagna.

Ženidbene spise i dio općih spisâ sredio je župnik, a ostalo je bilo nesređeno. Ukupno je popisano 65 svezaka i 78 svežnjeva.

Sa radom smo započeli u 8 , a (str. 21) završili u 20 sati. Navečer smo posjetili župnika u Kanfanaru i dogovorili se s njime za popisivanje. (J. J.)

Ivan Grah Jakov Jelinčić

Rudi Koraca

51. Kanfanar, 16.11.1972. (i Barat - kapelanija)

Izvršili smo popis građe u Kanfanaru. Župa Kanfanar nastavak je župe u Dvigradu. Spisi su dosta dobro sređeni i, koliko izgleda, prilično potpuni.

Rad započeli u 10, a završili u 18 sati. (J. J.)

Janko Gortan Ivan Grah Jakov Jelinčić 


\section{3. (godina) $)^{27}$}

(str. 22) 52. Grdoselo, dne 8.2.1973

Zahvaljujući ranijem radu oko sređivanja spisa što je izvršio domaći župnik Kurelović Franjo $^{28}$ bez poteškoće odijelio sam građu na dva fonda tj. župnog ureda Grdosela i samostalne kapelanije Kršikle. Zatim sam svaki fond podijelio na knjige i spise, poredao ih kronološki i prišao popisivanju najprije župskog fonda onda kapelanskom (! - J. J.). Župni fond posjeduje 35 svezaka knjiga i 20 svežnjeva spisa. Kapelanski je fond vrlo manjkav: vjerojatno je ta građa pomiješana s građom župe Grimalda. U fondu sam mogao nabrojiti 14 knjiga i 10 svežnjeva spisa. Jedan svezak urudžbenog zapisnika vraća se Grimaldi, jer (!) vjerojatno zabunom došao u fond Kršikle. Starije mat. knjige (XVIII. st) trebalo bi restaurirati. Pored starih mat. knjiga posebno su važni Popis imovine i prihoda od 1688. i župna kronika (br. 9,16 i 9,17). Radio od 10 do 17 sati. (I. G.)

Ivan Grah, sveć.

\section{Sveti Petar u šumi (! - J. J.), dne 19.2.1973.}

Danas smo sredili i popisali građu župnog arhiva u ovoj župi: knjige smo zaveli pod brojeve od 1 do 9, a spise pod brojevima 10-12. Građa ovoga fonda manjkava je pogotovo što se tiče spisa. Od vrjednije građe ističemo razne spise - inventare, oporuke, alegate, spise o hrvatskoj čitaonici, historijat župe i samostana i o seoskoj blagajni. Trebalo bi restaurirati jedan svezak Stanja duša (7,5). (str. 23) Radom smo započeli od 9 sati i završili u 17 sati. U radu nam je pomogao i domaći župnik. (J. J.)
Ivan Grah
Petar Pahović
Jakov Jelinčić

\section{Buzet, dne 21.2.1973.}

Danas smo radili na građi buzetskog župskog ureda, dekanata i kaptola. Konačno su popisane knjige župskog ureda, opći i ženidbeni spisi župskog ureda te građa kaptola. Preostalo je sređivanje računskih spisa župskog ureda te dekanatske knjige i spisi. Sređeno (popisano) ukupno 100 knjiga i 101 svež. spisa. U radu je neprekidno pomagao župski suradnik Branimir Petrović.

Radili smo od $9^{30}$ do 20 sati. (J. J.)

Jakov Jelinčić $\quad$ Branimir Petrović $\quad$ Ivan Grah

55. Buzet, dana 28.2.1973.

Danas smo nastavili rad na popisivanju građe koja se nalazi u župskom uredu u Buzetu. Završili smo sa popisom spisâ župskog arhiva te sa pisanjem inventara dekanatskoga arhiva. Osim toga napravili smo i inventar građe koja se odnosi na župu Črnica. U radu

27 Dodao J. J.

28 Ispravno: Frane. (J. J.) 
su nam pomogli župnik - dekan Stanko Macuka i njegov pomoćnik Branimir Petrović29. Posao smo započeli u 9 sati, a završili u (str. 24) $13^{30}$ sati. (J. J.) Za popodne je u planu popis građe u Sovinjaku. (I. G.).

Ivan Grah Stanko Macuka Banimir Jelinčić

56. Sovinjak, dne 28.2.1973.

Danas po podne od 14 do 18 sati odijelili smo, složili i popisali arhivsku građu ovoga fonda. Knjige smo zaveli pod brojevima od 1,1 do 9,5, a spise od 10,1 do 13,8. Pri radu je pomagao župnik Petrović Aleksandar. (I. G.)

Ivan Grah $\quad$ B. Petrović $\quad$ Jakov Jelinčić

57. Vrh, dne 1.3.1973.

Danas smo u rekordnom vremenu popisali građu ovoga fonda. Spise je trebalo prije podijeliti, zatim u rediti po godinama i popisati. Knjige smo zaveli pod brojeve od 1,1. do 9,19, a spise od 10,1 do 13,2. U radu su pomogli domaći župnik Stjepan Cvitić i susjedni Petrović Aleksandar. Radom započeli u 14 sati, i završili u 18 sati. (I. G.)
Ivan Grah
Cvitić Stjepan
J. Jelinčić

\section{Račice, 1.3.1973.}

Dio građe ovoga fonda nalazi se na Vrhu, a dio (starije građe) u samom sjedištu. Građa je sada sređena i nalazi se u župnom uredu Vrh. Knjige smo zaveli pod br. 1,1 do 8,2, a spise od broja 9,1 do 11,1. Radom započeli u 16 sati a završili u 20 sati. Dio vremena utrošili smo u diobu fondova. (I. G.)
Ivan Grah
Cvitić Stjepan
J. Jelinčić

(str. 25) 59. Lanišće, dana 27. kolovoza 1973.

Danas smo se uputili u ovu župu koja graniči s Riječkom [Riječko-senjskom nadbiskupijom - J. J.] i Koparskom [biskupijom - J. J.] i jednom bogatom pučanstvom a sada u izumiranju. Radom smo započeli u 9s i uz mali predah radili do 23 sata. Popisali smo u glavnom svu građu koja se nalazi dobro sačuvana i prilično sređena, ima je oko 10 metara. Od vrijedne građe ima nekoliko prijepisa pergamena iz Rašporskog kapetanata o običajnom pravu izbora župnika. Vrlo je bogata dokumentacija o gradnji župne crkve. Talijani su bili nametnuli Lanišću novi naziv još 1920. godine „Milino“, ali se zadržao svega nekoliko godina. (I. G.)

Ivan Grah Petar Matijašić Jakov Jelinčić

29 Radi se o Branimiru Petroviću (u: BARTOLIĆ - GRAH, Crkva u Istri..., str. 183: pod r. br. 62.: PETROVIĆ BRANIMIR ALEKSANDAR). (J. J.) 


\section{Brest, 28. kolovoza 1973.}

Danas smo od 7 do 8 sati popisali građu ovoga fonda koja je vrlo oskudna. Župa postoji od 1906. godine jer je ranije bila u sastavu župe Lanišće, gdje se nalaze ranije spisi i knjige. Od arhivske građe ove župe danas postoje jedino mat. knjige, koje su oduzete i nalaze se u mjesnom uredu u Danama. Ostalu građu uništila je vojska koja se 1944. bila uselila u župni stan. U njemu se uselila njemačka vojska. (I. G.)

Ivan Grah

Petar Matijašić

Jakov Jelinčić

(str.26) 61. Slum, 28. kolovoza 1973.

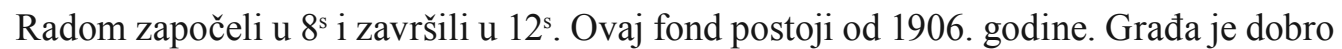
sačuvana $^{30}$ ali je manjkava, mat. knjige bile su oduzete i sada se nalaze u mj. uredu Dane (Rijeka). Ostala se građa čuva i registraturno vodi u župi Lanišće. Od g. 1906 do 1949 u sastavu župe bio je i slovenski dio kapelanije Rakitovec koja je sada samostalna kapelanija pod upravom Ap. Ad. (Apostolske administrature - J. J. ${ }^{31}$ ) Koper. Prigodom diobe predan je Rakitovcu i dio stanja duša koji se na nj odnosi. (I. G.)

Ivan Grah

Petar Matijašić

Jakov Jelinčić

62. Hum, dne 28. kolovoza 1973.

Naišli smo na vrlo dobro uređenu građu i strogo odijeljenu po predmetima. Naročito ima mnogo svežnjeva službenih spisa (49) obzirom na svoju veličinu. Radom smo započeli u $14^{\mathrm{s}}$ i završili u $18^{30}$. Pronašli smo 6 pergamena i uzeli ih za restauraciju. (I. G.)

Ivan Grah Vidau Josip, župnik Jakov Jelinčić

63. Roč, 28. kolovoza 1973.

Sređivanjem ovoga fonda počeli smo u $20^{\text {s }}$ i radili do $23^{\text {s. }}$. Kroz to smo vrijeme uspjeli podijeliti građu na knjige i spise. (I. G.)

Ivan Grah

[Jakov Jelinčić]

(str. 27) 64. Roč, 29. kolovoza 1973.

Radom smo nastavili u $7^{30}$ i uz mali prekid radili do 17 sati. Građu smo najprije sredili, detaljno podijelili, spise složili i prišli popisivanju: knjige pod matičnim brojevima od 1 do 10 i spise od 11 do 14. Najvrijednija građa ovoga fonda jesu pergamene ( ) /!/ koje su bile restaurirane 1972. godine u Zagrebu, zatim nekoliko svežnjeva spisa zavedenih pod razno. Već su ranije bili odvojeni najoštećeniji spisi, koje smo pronašli u dva različita mjesta te ih sjedinili u jedan svežanj i zaveli ih pod br. 14,14. Ovi spisi trebali bi nužno biti restaurirani. U radu je pomogao domaći župnik. Do g. 1843 župom je upravljao kolegijalni kaptol,

$30 \quad$ Trebalo bi stajati: uščuvana. (J. J.)

31 Tadašnja je administratura danas Koparska biskupija. (J. J.) 
a dalje župnik. Budući da ima vrlo malo spisa kaptolskih i budući da se ona (!) nastavlja uveli smo sve u jedan fond. Novije mat. knjiga nalaze se u mjesnom uredu u Roču. (I. G.)
Ivan Grah
Ratislav Udovičić
Jakov Jelinčić

Opaska: arhivska građa fondova: Lanišće, Brest, Slum, Hum i Roč bila je odmah otkucana mašinom u 10 primjeraka, svaki primjerak uvezan, potpisan i jedan primjerak ostavljen tvorcu građe. (I. G.)

Ivan Grah

Jakov Jelinčić

\section{Kršan, 1.9.1973.}

Danas smo sređivali tri fonda, tj. župni Kršana i Kožljaka i dekanatski Kršan. Građa je bila prilično sređena, ali vrlo pomješana. Stoga je trebalo najprije podijeliti i sre- (str. 28) diti građu po fondovima i zatim po predmetima. Trebalo je 7 sati rada da se to izvrši. Zatim smo prešli na popisivanje građe župe Kršan. Radom smo započeli u $8^{\mathrm{s}}$ i završili u 15 sati. (I. G.)

Ivan Grah Grubišić Anđelko [župnik] Jakov Jelinčić

66. Kršan, 1.9.1973.

Zatim smo prešli na popisivanje građe Kršanskoga dekanata i zaveli knjige pod brojeve od 1 do 5 , a spise pod broj od 6,1 do 6,13. Ovaj je fond dobro sačuvan i ima relativno mnogo građe. Radili od 15 do 18 sati. (I. G.)

Ivan Grah Grubišić Anđelko Jakov Jelinčić

\section{Kožljak, 1.9.1973.}

Jednom odijeljena građa nije zadala naročitu brigu da se kronološki i predmetno poreda u svežnjeve i zatim popiše. Ova je građa manjkava, a čuva se u župnoj kući u Kršanu u posebnim ormarima. Radili smo od 16 do 20 sati. (I. G.)

Ivan Grah Grubišić Anđelko Jakov Jelinčić

68. Plomin, 10.10.1973.

Ovaj nam je fond zadao mnogo posla, jer je građa bila u rasutom stanju. Najviše su nam posla zadali spisi dok smo ih barem donekle sredili za popisivanje. Nažalost starije građe nema i ako (!) je ovdje bio kolegijalni (str. 29) kaptol do druge polovice XIX stoljeća. Ima svežnjeva starijih spisa, ali su pretežno kopije. ${ }^{32}$ Građa je prilično oštećena od kiše i vlage te bi je trebalo smjestiti u sigurniju prostoriju. $U$ fondu smo našli i desetak knjiga arhivskog fonda Kožljak te su tamo vraćene (ima ih 14) (J. J.).

Ivan Grah

Jakov Jelinčić

32 Ovdje se ne radi o preslikama u današnjem smislu nego o prijepisima. (J. J.) 
69. Grožnjan, 24. listopada 1973.

Ovaj smo fond našli u vrlo dobrom stanju i sređenu (!) i ako (!) je za vrijeme rata i poslije bio u opasnosti. Sredio ga je današnji župnik Gallo Irenko. Fond ima prilično arhivske građe, ali uglavnom novije. Starija je građa bila deponirana u arhivu Grožnjanske općine. Taj je arhiv bio spaljen 1943. godine po nalogu domaćih ljudi koji su preuzeli vlast od talijana (!) i kao prvi čin spalili sav fond arhiva, tako je stradala i crkvena građa. Iz ranije je literature poznato da su tamo bile deponirane neke pergamene i dva kodeksa: Statut Grožnjana i Život svetaca. Radom započeli u 7 ${ }^{\mathrm{s}}$, završili u 12 sati. (I. G.)
Ivan Grah
Gallo Irenko
Jakov Jelinčić

70. Kostanjica, 24. listopada 1973.

Arhivska se građa nalazi u župnom uredu Grožnjana, dobro je uščuvana i složena. Župa je u raslojavanju i izumiranju tako da novije građe gotovo i nema. Radili od 12 do 15 sati. (I. G.)

Ivan Grah Gallo Irenko Jakov Jelinčić

(str. 30) 71. Krasica, 24. listopada 1973. god.

Popisao knjige (petnaestak komada) najprije sam ih odvojio od građe župe Grožnjan i Kostanjica, a zatim ih sortirao i popisao. Od 15 do 16 s. (J. J.)

Ivan Grah Gallo Irenko Jakov Jelinčić

72. Materada, 25. listopada 1973.

Danas smo radili na fondu ove župe. Građa je bila pravilno sređena do 1924. godine. Ustanovili smo da fale najstarije matične knjige iz XVII st. da su podaci unosili (!) u matici za kratko vrijeme kurzivom glagoljicom, da fale spisi od 1931 do 1935 u većem dijelu. Naišli smo na bilješku koja govori da je ondašnji župnik akte jednostavno bacao u koš mjesto da ih arhivira. Tada je bio župnik Ferdinand Orti. U ovoj se župi čuvaju tekuće matične i upravne knjige umaške kapelanije Petrovog sela ${ }^{33}$ i bujske kapelanije Kršete, dok se starije knjige i spisi čuvaju u Umagu i u Bujama. Radom započeli u 7 sati do 17 sati. (I. G.)

Ivan Grah Alojzije Baf Jakov Jelinčić

\section{Brtonigla, 27.11.1973. i Nova Vas (Novigradska) $)^{34}$}

Danas smo razvrstali i popisali građu župnog ureda u Brtonigli. Građa je dosta dobro sačuvana. Nalazi se na drvenim policama i povezana je u svežnjeve. Župnik se interesira za građu i (str. 31) s vremenom će je srediti po godinama. Najstarija knjiga je iz 1583.

33 Danas: Petrovija. (J. J.)

34 Nova Vas nad Mirnom. (J. J.) 
(matična knjiga krštenih) /do 1666. - J. J./. Postoje i dvije pergamene iz 1548. (restaurirane odnosno izravnane u laboratoriju Arhiva Hrvatske u Zagrebu). ${ }^{35}$

$\mathrm{Na}$ ovom fondu smo radili od 10 do 17 sati (s malom pauzom za ručak.

Nakon toga smo pristupili radu na popisivanju građe župnog ureda Nova Vas novigradska. Građa se čuva u ž. uredu u Brtonigli pod istim uvjetima kao i već spomenuta građa ž. ureda u Brtonigli. Građa je također dosta dobro očuvana. Najstarija knjiga je knj. ljetnica (Litnice) iz kraja 18. st. i 19. st. na hrvatskom jeziku. Građu smo popisivali od 17 do 20 sati. Župnik je pomogao u sređivanju. (J. J.)
Ivan Grah
Ivan Krajcar
Jakov Jelinčić

\section{4. godina}

\section{Vrsar, 20.2.1974.}

Danas smo razvrstali i popisali građu župnog ureda u Vrsaru. Građa je dosta dobro sačuvana. Od 1922. god. do 1945. sačuvano samo nekoliko spisa po godištu. Župnik smatra da je dio građe nastao u periodu fašizma uništen za vrijeme rata. ${ }^{36}$ Granične godine: 1562. do danas. U tzv. župnim spisima nalaze se i ženidbeni. Građa ovog ureda je tim važnija jer nam dozvoljava uvid u period za koji nam je zagubljen arhivski materijal porečke općine pod koju je spadao (str. 32) i Vrsar. Ovdje je sa arhivističkog stanovišta interesantno napomenuti da smo naišli na novu grupu spisâ, tzv. Pezze d'appoggio. Ti se spisi inače vode uz ostale spise (u ostalim fondovima). To su ustvari dopunski spisi. Mi smo ih uvrstili u grupu 'Razno' i nazvali ih 'dopunski spisi'.

Radom smo započeli u $9^{30}$, a završili u 17 sati.

U radu nam je pomagao župnik gosp. Ivan Jelovac, koji se veoma zanima za arhivsku građu i na temelju iste kani napisati historijat Vrsara. ${ }^{37}$ (J. J.)

Ivan Grah Ivan Jelovac Jakov Jelinčić

\section{Funtana, 20.2.1974.}

Nakon gornjega otišli smo u Funtanu i tamo popisali građu župnog ureda. Građa je vrlo dobro sačuvana. Svi spisi se vode zajedno, a od 1949. god. se odvajaju ženidbeni spisi. Građa počinje sa 1815. Samo jedan stariji spis (1792.).

U radu na popisivanju pomogao nam (str. 33) je župnik Ivan Jelovac. (J. J.)

Sa radom započeli u $17^{15}$, a završili u $19^{15}$.

Ivan Grah Jvan Jelovac Jakov Jelinčić

35 Danas, nakon 43 godine, sjećam se da mi je župnik rekao kako ih je skupo platio (cijene se ne sjećam, ali se radilo, čini mi se, o njemačkim markama) što ukazuje na njegov osjećaj za vrijednost arhivskoga gradiva. (J. J.)

36 Tekst koji počinje s 'Od' do 'dio' nalazi se na podnožju str. 31, a od 'građe' do 'rata' na podnožju str. 32. (J. J.)

37 U tome nije uspio, vjerojatno i zbog narušena zdravlja, prometne nesreće i velike zauzetosti oko gradnje zvonika jer je Vrsar bio jedna od rijetkih župa čija župna crkva nije imala zvonika. (J. J.) 


\section{Baderna, 26. veljače 1974.}

Radom smo započeli u 8 sati i završili u 14 sati. Najprije smo morali podijeliti građu na grupe, jer je ona bila složena kronološki: knjige smo zaveli u grupe od 1 do 10 , a spise od 11 do 14. Spisa ima 40 svežnjeva, građa je mlađa, koristo se njome domorodac Ernest Radetić u svojoj djelatnosti. U radu je pomogao župnik Ritoša Zorko. (I. G.)

Ivan Grah Zorko Ritoša Jakov Jelinčić

77. Sv. Ivan od Šterne, 26. veljače 1974.

Radom smo započeli u $14^{30} \mathrm{i}$ radili do 17 . Ovaj nam je fond zadao brige jer je građa bila djelom neuređena i pomiješana s fondom župe Muntrilj. Građa je bila kronološki poredana, ali samo djelomično. Odvojili smo fondove, ali samo za neke godine, jer se građa pretežno odlagala zajedno. Arhiv je prilično bogat, starije matične knjige nalaze se u Arhivu u Pazinu. Ovaj je fond pisan pretežno hrvatski. Knjiga ima 8 grupa, a spisa 4 ili ukupno 45 svežnjeva. (I. G.)
Ivan Grah
Zorko Ritoša
Jakov Jelinčić

78. Muntrilj, 26. veljače 1974.

Građa se pretežno nalazi u župnom uredu Sv. Ivana od Šterne, (str. 34) a novija u Kringi, pretežno najnovija. Građu smo počeli sređivati u 17 sati i završili u 18 sati: našli smo 4 grupe. (I. G.)

Ivan Grah Zorko Ritoša Jakov Jelinčić

\section{9. Žbandaj, 26. veljače 1974.}

Iz Sv. Ivana od Šterne prešli smo u Žbandaj gdje smo našli fond lijepo uređen, građu podijeljenu. Radom smo započeli u $18^{30}$ i radili do 23 sata. ${ }^{38}$ Odvojili smo građu fonda Fuškulin, da se otpremi u onaj fond. Ovaj je župni fond (žbandajski - J. J.) vrlo bogat, građa je pisana pretežno talijanski, jer su župom upravljali po tradiciji talinski (!) svećenici za razliku od susjednih župa koje su vodili mahom hrvatski svećenici. Knjige smo uveli u 8 grupa, a spise, a spise (!) u 4. Spisa ima 46 svežnjeva. (I. G.)
Ivan Grah
Zorko Ritoša
Jakov Jelinčić

38 Ovaj ću najduži radni dan na terenu pri popisivanju istarsko-crkvenoga gradiva pamtiti dok me pamćenje bude služilo. Krenuli smo iz Žbandaja nešto prije ponoći. Oko ponoći bili smo u Tinjanu gdje nam je u Grahovu Fići zakuhala voda (premda je bilo hladno). Čekajući dok se hladnjak ohladi, ondje nas je dočekao novi dan. Treba reći da je dan u kojem smo obišli četiri župe (uvijek isti župnik), bio pokladni (u istarskom dijalektu: pus'ni) utorak, a Graha su čekale pobožnosti Čiste srijede (koju smo dočekali u Tinjanu). Navečer sam otišao do njega u Gračišće, a njegova draga majka, legendarno gostoljubiva teta Ana, dočekala me uz smiješak: „Neka van tako bude kad grete okoli k’o dva pusta (karnevala).“ Svi smo se slatko nasmijali i tako, nakon mise, dočekali posnu večeru. (J. J.) 
80. Tar, 5. ožujka 1974.

Ovaj je arhivski fond zapravo ostatak ostataka građe koja je popala (!) kad ju je vojska izbacila preko prozora u vrt kad se nastanila 1948. godine u župnom stanu Tara. Svega desetak matičnih knjiga i jednu pergamenu spasio je neki talijanski učitelj ondje nastanjen uz pomoć jednog dječaka. Sačuvana građa pripadala je župama Taru, Vabrigi i Frati koje su se 1848. godine sjedinile pod nazivom župa Tar. Matične su knjige vođene djelomično i glagoljicom. Postoji i popis župnika u trim župama iz XVII st. dalje, stari inventar i druge zanimljivosti. Radio od 10 do 15 sati. (I. G.)

Ivan Grah

(str. 35) 81. Višnjan, 6. ožujka 1974.

Danas ujutro smo radili na popisivanju arh. - reg. (registraturne - J. J.) građe župnog uredu u Višnjanu. Fond je dobro sačuvan i prilično dobro sređen.

Knjige smo rasporedili u 8 grupa, a spise $\mathrm{u} 4$ grupe. Osim toga postoje 2 mansionerije. ${ }^{39}$ U radu nam je pomogao mjesni župnik Vladimir Rebek (J. J.)

Ivan Grah Vladimir Rebek Jakov Jelinčić

82. Bačva, 6. ožujka 1974.

Mj. župnik iz Višnjana upravlja excurendo ${ }^{40}$ župom Bačva, pa se i arhiv čuva u Višnjanu. Arhiv je dosta slabo sačuvan. Župniku su rekli župljani da je za vrijeme rata arhiva bila razbacana po selu. Šteta, jer radi se o vrlo staroj župi.

Sačuvano je nekoliko knjiga koje smo rasporedili u 8 grupa i svega 2 svežnja spisâ, raspoređenih u dvije grupe: opće i ženidbene.

U radu nam je pomogao mjesni župnik V. Rebek. (J. J.)

Radili od $11^{30}$ do $13^{\mathrm{h}}$.

Ivan Grah

Vladimir Rebek

Jakov Jelinčić

(str. 36) 83. Nova Vas Porečka, 6. ožujka 1974.

Danas po podne počeli smo sređivati ovaj fond. Lako smo odijelili knjige od spisa. Knjige smo uveli u popis međutim bilo je nemoguće isti (!) učiniti sa spisima jer su spisi bili vezani u nekoliko svežnjeva bez ikakvog reda i označeni slovima od A do S. Dogovorno sa župnikom knjige ćemo odvesti u Gračišće gdje ćemo ih moći vremenom podijeliti po predmetu i kronološki. Taj će posao iziskivati puno vremena. Kad budu sređeni i popisani bit će vraćeni tvorcu. Radili smo u sjedištu fonda od 14 do 16. (I. G.)

Ivan Grah

Ivan Kelčec

Jakov Jelinčić

39 Mansionarija / mansionerija - crkvena nadarbina.

40 Pravilno: excurrendo. Vidi bilješku br. 20: ekskurirati. (J. J.) 
84. Kringa (Muntrilj), 12. ožujka 1974.

Danas popodne radio sam u Kringi na popisivanju građe župe Muntrilj. Popisao sam knjige. Radio sam od 16 do 18 sati. (J. J.)

\section{Jakov Jelinčić}

\section{Nova Vas kod Poreča, 14. ožujka 1974 (radio u Gračišću)}

Danas sam počeo s radom na sređivanju spisa ovoga fonda koji su u rasutom stanju, i ako su bili vezani u svežnjeve raznih veličina ali bez ikakva reda. Izgleda da su spisi bili arhivirani u dvije, najviše tri grupe: opći spisi pod nazivom „atti misti“, računski spisi i možda razni. Radom započeo u 9 sati do 12 , i od 15 do 22 sata. (I. G.)

Ivan Grah

(str. 37) 86. Viž̈inada, 20.3.1974. (srijeda)

Radi spriječenosti gospodina Graha danas sam sâm došao u Vižinadu. Radio sam na sortiranju i popisivanju pomoćnih knjiga. Kada sam to završio prišao sam sortiranju vrlo bogate serije knjiga bratovštinâ i tako pripremio posao za idući dan. Radio od $10^{30}$ do $19^{30}$ s. Pri radu mi je pomogao župnik, vlč. gosp. Josip Sinožić. (J. J.)

$$
\text { Josip Sinožić Jakov Jelinčić }
$$

\section{Vižinada, 21.3.1974. (četvrtak)}

Radili smo kao i obično (Grah na spisima, a Jelinčić na knjigama). Spisi i knjige su vrlo dobro sačuvani. Radi se o veoma bogatom fondu koji je tim vrijedniji što je zagubljena građa civ. (civilne - J. J.) jurisdikcije, a i motovunske kancelarije.

Grah je započeo posao u $8^{30}$, a Jelinčić u $11^{\text {h}}$. Posao smo uz obilnu pomoć župnika završili u $20^{30}$ sati. (J. J.)

Ivan Grah Josip Sinožić Jakov Jelinčić

\section{Nova Vas kod Poreča, 26. ožujka 1974 (radio u Gračišću)}

Danas sam uspio podijeliti građu ovog fonda (samo spise) i to na opće spise, ženidbene, računske i razne. (str. 38) I ako fond nije bogat građom zadao je mnogo brige i posla jer je građa bila podijeljena u svežnjeve, ali bez ikakvoga kriterija. Za taj sam posao utrošio oko 10 sati intenzivnoga rada, jer je trebalo svaki spisi (!) pregledati, datirati i podijeliti u grupe. Ženidbeni spisi bili (!) i ranije odlagani zajedno s općim spisima, pa sam ih tako i pustio do 1913. Iz starijih se spisa može vidjeti kako je bilo bijedno ekonomsko stanje doseljenika u XVII stoljeću. (I. G.)

Ivan Grah 
89. Nova Vas kod Poreča, 6. svibnja 1974 (radio u Gračišću)

Danas sam konačno sredio svežnjeve, uvezao ih i numerirao: općih spisa ima 37 svežnjeva, ženidbenih 2, računskih 4 i raznih - pretežno štampanih (vrlo važnih) stvari 3. Vrlo su manjkavi spisi od 1924 do 1945 godine. Za taj sam posao utrošio oko 5 sati rada. Fond će prvom prigodom biti vraćen tvorcu. (I. G.)

\section{Ivan Grah}

\section{Sveta Marija na Krasu, 16. svibnja 1974.}

Danas smo podijelili fond ove župe, koji je relativno mlad. Raniji se spisi nalaze, a i knjige u fondu župe Kaštel od koje je 1946. godine bila odijeljena i proglašena župom Sveta Marija na Krasu. Radom smo započeli u 8 sati i završili u 12. Prije usput (!) posjetili i pregledali fond u Lovrečici. Nekoliko godišta spisa nalazi se vjerojatno u Savudriji. (I. G.)

Ivan Grah

Jakov Jelinčić

(str. 39) 91. Kaštel, 16. svibnja 1974.

Nekoliko smo svežnjeva spisa donijeli iz Svete Marije na Krasu i kompletirali ovaj fond koji je bogatiji, ali nema vrijednije građe. Starija građa fali kao i najstarije matične knjige koje su bile pisane i glagoljicom. Grđa je bila ranije pohranjena u župnom uredu i nedavno zbog vlage premještena u sakristiju. Prilično su oštećeni i spisi više godišta zbog vlage i glodavaca. Knjige smo podijelili u 7 grupa, a spise u 4. Radom smo započeli u 13 sati i završili u 18. Usput smo pregledali građu fonda Ritošinoga Briga i dogovorili se za daljnji rad. (I. G.)

Ivan Grah

Jakov Jelinčić

92. Sv. Vital (Ritošin Brijeg), 20. svibnja 1974.

Danas smo sredili i popisali građu u ovom župnom uredu. Kurentne knjige nalaze se u Vižinadi odakle ekskurira ž. upravitelj vlč. gosp. Josip Sinožić.

S poslom smo započeli u 8 s., a završili u $15^{\text {h}}$. Usput posjetili arhive u Motovunu i Mot. Novakima - do $17^{00} \mathrm{~s}$.

Ivan Grah

Jakov Jelinčić

93. Grimalda, 28. svibnja 1974.

Danas smo sredili i popisali građu ovoga župnog fonda. Građe ima relativno malo. Jedan svežanj važnijih spisa iz fonda kapelanskog ureda Kršikle preuzeli smo (str. 40) da vratimo tvorcu fonda koji se čuva u župnom uredu u Grdoselu. Radom započeli u $12^{30} \mathrm{i}$ završili u 16 sati. (I. G.)

Ivan Grah

Koren Milivoj, sveć.

J. Jelinčić 
94. Draguć, dana 28.5.1974.

Ovaj je fond bio u rasutom stanju te ga bio (!) započeo sređivati gosp. Ante Bogetić ${ }^{41}$. Mi smo nastavili radom, podijeli (!) fond na knjige i spise, poredali ih kronološki, sredili i popisali. Ima praznina u spisima jer povremeno manjkaju pojedina godišta općih spisa. Radom započeli u $16^{30}$, a završili u 21 sat. U radu nam je pomogao mladi upravitelj župe Koren Milivoj.

Ivan Grah

Koren Milivoj, sveć.

J. Jelinčić

95. Gračišćé (Kršikla - J. J.), 30. svibnja 1974.

Danas sam sredio jedan svežanj razne građe koju sam odvojio od fonda kapelanskog ureda Kršikla. Radio od 9 do 11 sati. (I. G.)

Ivan Grah

96. Poreč, 12. lipnja 1974.

Današnjim danom započeli radom na fondovima koji se čuvaju u župnom stanu Poreč. Radi se najmanje o tri fonda: kaptolski, dekanatski i župni. Ja sam uspio srediti, poveza(str. 41) ti u svežnjeve građu dekanatskog fonda, koja je prilično manjkava. Od knjiga ima samo urudžbeni zapisnik koji je također manjkav. Građu sam zatim popisao, označio i poredao u ormar. Zatim sam započeo radom na spisima župnog ureda. Prof. Jakov Jelinčić dao se na posao sređivanja kaptolskog fond (!) koji je prilično bogat. Tokom svoga rada nije uspio ni pregledati i datirati sve komade koji se u fondu nalaze. Radom smo započeli u $9^{30}$ sati i uz mali prekid nastavili do $20^{30}$. (I. G.)

Ivan Grah

Jakov Jelinčić

97. Poreč, 20. lipnja 1974.

Radili od 14 do 20 sati. Prof. Jelinčić uspio je podijeliti po predmetu, a unutar predmeta kronološki knjige kaptolskog fonda. Rad mu je otežan zbog pomanjka prostora. Ja sam uspio srediti i označiti ženidbene spise, zatim sam popisao ženidbene i opće i složio ih kronološki u ormar. Zatim sam počeo sređivati računske spise koji su obilni. Bit će i više svežnjeva raznih spisâ. (I. G.)

Ivan Grah

Jakov Jelinčić

98. Porě̌, 2. VII 1974.

Današnjim radom postigli smo to da sam ja složio i popisao najprije računske spise, a zatim razne spise, a prof. J. Jelinčić još je jednom kontrolirao podijelu građe i dao se na popisivanje. Ističem da među spisima ima vrijedne gra- (str. 42) đe s raznom tematikom kao što je historijat Porečkih crkava, čime se koristio povjesničar Babudri i pisao u Atti e

${ }^{41}$ Kasniji biskup porečki i pulski (1984. - 1997.). (J. J.) 
memorie, zatim stari inventari, popis (!) i druga građa kanonika Pesantea o staroslavenskoj službi Božjoj, spisi o kongresima i građa o okupaciji Istre. Mnogo je vrijednija građa Kaptolskog fonda, čiju smo građu povezali u veće svežnjeve po predmetu i kronološki. Napominjem da ima knjiga koje su glomazne kao i vrlo malih. Da se umanji broj komada svezali smo više manjih knjiga i zaveli ih u popis kao jedinicu. Radom smo započeli u 7 sati i uz male predahe radili do 19,30. (I. G.)

Ivan Grah

Jakov Jelinčić

99. Poreč, 3. srpnja 1974.

Danas smo nastavili s popisivanjem i numeracijom Kaptolskog fonda i došli do jedinice broj 68, no svaka jedinica ima od jedne veće do preko 30 manjih ili najmanjih knjiga. Poteškoće nam predstavlja činjenica što su formati knjiga vrlo različiti pa zbog pravilnijeg smještaja u ormaru ne možemo se držati uvijek kronologije unutar predmeta. Preostala je još posljednja grupa tj. razne knjige i spisi koje će trebati, datirati, srediti u neke cjeline i inventarizirati. Naišli smo na nekoliko pergamena koje su vrlo oštećene kao i na pojedine predmete koji sižu (!) u XII stoljeće. Na tom smo fondu radili od 9 do 14 sati. Zatim sam ja nastavio sa sređivanjem knjiga župnog fonda: knjige sam podijelio u šest grupa. Napominjem da od matičnih knjiga nema knjiga (str. 43) krštenih, vjenčanih ni umrlih, jer su najstarije u Hist. arhivu u Pazinu, novije u Matičnom uredu u Poreču, dok se najnovije vode kao registratura. Rad sam prekinuo u 18 sati. (I. G.)

Ivan Grah

Jakov Jelinčić

100. Paz, 24. srpnja 1974.

Ovaj fond mi nije dao naročitoga posla, jer je bio svojevremeno dobro sređen. Knjige sam podijelio u 9 grupa, a spise u četiri. Radom sam započeo u 8 sati i završio u 14. Među spisima nisam naišao na nešto naročito, a među knjigama napominjem mat. knjige krštenih, vjenčanih i umrlih od 1751. (I. G.)

Ivan Grah

\section{Poreč, 25. srpnja 1974. i Fuškulin}

Danas smo nastavili s radom na kaptolskom fondu i ujedno prešli na novi fond župe Fuškulin. Građu je ovoga fonda župnik dopremio u Poreč gdje će se za dalje čuvati. Prof. Jelinčić je uspio popisati razne dokumente Porečkog kaptola, ali su mu još preostali kaptolski spisi. Ivan Grah je uspio srediti, označiti i popisati građu župe Fuškulin: knjiga ima malo, ali je spisa mnogo s obzirom na tako malu župu. Radom smo započeli u $8^{\mathrm{s}}$ i završili u 17. (I. G.)

Ivan Grah

Jakov Jelinčić 
(str. 44) 102. Poreč, 27. VIII 1974.

Danas sam konačno završio sa sređivanjem i popisivanjem kaptolskog fonda u Poreču. Bili su preostali kaptolski spisi koje sam sredio predmetno i kronološki u 25 svežnjeva. Ustanovio sam da u par svežnjeva ima nešto strane građe tj. iz župnog fonda. Kad sam sredio i spremio ovu građu naišao sam na treći svežanj najstarije građe iz dekanatskog fonda i ogroman svežanj ${ }^{42}$ Urudžbenog zapisnika župnog fonda od 1849. do 1947. godine: ovu građu treba podijeliti na 10 jedinica. Radom započeo u 8 sati i radio neprekidno do 10 sati. Zbog skučenosti prostorije i pomanjkanja prostora rad nam je u Poreču bio otežan i nismo mogli građu najbolje podijeliti prije popisivanja. Naišao sam i na 21 pergamenu, mahom novijega datuma. (I. G.)

\section{Ivan Grah}

\section{Gradina kod Poreča, 27. kolovoza 1974.}

Župnik je građu ovoga fonda dopremio u župni stan župe Svetog Lovreča gdje sam je podijelio, složio i popisao. Vrijedne su starije mat. knjige iz 1720. dalje, ima čak nekoliko glagoljskih upisa u mat. krštenih 1807. i 1808. godine. Spisa ima 30 svežnjeva, međutim ima i praznina, jer nekoliko godišta općih spisa fali. Građa će biti pohranjena u župnom stanu u Svetom Lovreču, jer u Gradini nema župne kuće pa se građa čuvala u sakristiji. Današnjim radom završili smo s popisivanjem fondova u Porečkom dekanatu. Radio od $15^{30}$ do 20 sati. (I. G.)

\section{Ivan Grah}

\section{(str. 45) 104. Čepić, 2. rujna 1974.}

Danas sam se svratio u ovaj župni ured gdje se čuva građa susjednih župa Brda i Šušnjevice. Napominjem da se ova građa čuvala u župnom stanu Brda. Taj su župni stan zapalili fašisti i njemci (!) 1944. kad su kod župnika Križmanić Franja (!) našli partizansku propagandu i navodno nešto oružja. Župnik je bijegu (!) uspio spasiti život, ali je kuća bila spaljena. Na terenu sam doznao da je i općinski arhiv u Šušnjevici (Comune di Valdarsa, ili Frascati d'Istria) bio uništen neposredno iza rata. spalili (!) su ga, navodno, neodgovorni domaći ljudi. Starije se građe spasilo nekoliko jedinica i svežnjeva, jer su bili pohranjeni u Čepiću, Kršanu i Kožljaku i prigodom sređivanja vraćeni tvorcu. Naišao sam na svežanj spisa župe Kožljaka i župe Kringe i vratio tvorcima. Radio od 9 do 15 sati.

Ivan Grah

105. Umag, 23. listopada 1974.

Današnjim smo danom počeli sređivati i popisivati građu ovoga fonda. Građa je dobro uščuvana. Ustanovili smo da su neka godišta prigodom odlaganja u ormare zalutala iz fonda $u$ fond budući da smo naišli na početku rada na tri fonda: kaptolski, dekanatski i

42 Prema arhivističkoj terminologiji: svezak. (J. J.) 
župni. Ima građe iz susjednih župa koje su kasnije nastale te će barem knjige biti vraćene u svoj fond. Uspjeli smo srediti i popisati dekanatski fond koji ima oko 130 svežnjeva građe i par knjiga. Ovaj je fond relativno bogat, građa je gotovo sva sačuvana, ima (str. 46) 30 svežnjeva školskih spisa od 1818. do 1868. kad je dekan vršio službu nadglednika područnih škola. Zatim smo prešli na sređivanje kaptolskog fonda: građe ima sačuvane malo, ali je vrlo vrijedna. Građa je šivena u knjige malog formata (Vacchette) i srednjeg (dužnosti i prava kaptola). Radili smo od 8 sati do 20 uz prekid od $12^{30}$ do $13^{30}$. (I. G.)

Ivan Grah

\section{Umag, 29. listopada 1974.}

Danas smo nastavili s radom: najprije smo dovršili srediti i popisati kaptolski fond. Građa ima 40 svežnjeva u rasponu vremena od XV do XIX stoljeća. Fond nije naročito bogat po količini, ali je građa vrlo vrijedna, kad se zna da civilne građe gotovo i nema iz tog razdoblja. ${ }^{43}$ Zatim smo se dali na uređivanje župnog fonda: naišli smo na najstarije matične knjige krštenih od 1483. do $1693 .{ }^{44}$ Knjige smo podijelili u 8 grupa a spise u četiri. Spisa ima 130 svežnjeva, 2 pergamene iz XVII-XVIII st. i topografska karta iz 1721. Najvažniji su spisi zavedeni pod "razni spisi" koji datiraju od 1609. dalje. Radili gotovo neprekidno od 8 do 22 sata. (I. G.)

Ivan Grah

\section{(1975. godina) $)^{45}$}

107. Savudrija, 25. veljače 1975.

Danas smo popisali arhivsku građu ovoga fonda: građa je bila već uredno sređena i datirana. Najvažnija knjiga krštenih bila je oduzeta i ne zna se gdje se nalazi: vjerojatno u JAZU u Zagrebu. ${ }^{46}$ Važna je (str. 47) zbog upisa krštenja koja su bilježili trećoreci glagoljaši iz Pirana. Radom smo započeli u 8 sati i dovršili u $12^{15}$.

Ivan Grah Z Z(latko) Rupnik J. Jelinčić

43 Treba reći da su Englezi u dvama navratima palili umaški arhiv »Dopo qualche giorno alcune navi inglesi... e sbarcarono... bruciarono sulla piazza Atti dell'Archivio comunale..." (Andrea BENEDETTI, Umago d'Istria nei secoli, vol. II, Collana studi istriani del Centro culturale "Gian Rinaldo Carli", tipografia G. Coana, Trieste, 1975., str. 190-191). »Durante l'occupazione francese gli Inglesi erano sbarcati, come s'è detto, una seconda volta a Umago e, invaso il palazzo Comune, asportarono gli statuti, le carte e le pergamene della Vicedominaria e con atto veramente vandalico le bruciarono sulla piazza (27 marzo 1810.) (24) Così pure andarono distrutte per mano loro quelle di Rovigno come un anno prima erano state distrutte quelle di Caorle.« (Radi se o biskupijskom sjedištu u Italiji. Op. J. Jelinčić.); BENEDETTI, nav. $d j$., str. 193. (J. J.)

44 Otprilike su do 1608. prijepisi. Iz uvoda je vidljivo da je prijepis izvršen iz poderane knjige, a iz nalijepljenoga papirića na koricama knjige vidljivo je da je knjiga krštenih datirala iz 1400; ;idi: Ivan GRAH - Jakov JELINČIĆ, Inventar arhivsko-registraturne građe župnog ureda u Umagu od 29. listopada 1974. god., str. 1; Inventar se nalazi u DAPA-i. (J. J.)

45 Dodao J. J.

46 Na temelju knjige Vjekoslava ŠTEFANIĆA (Glagoljski rukopisi Jugoslavenske akademije, JAZU, Zagreb, 1970.), odnosno »Kazala« na kraju sveska br. II, u kojem se ne navodi navedena knjiga, zaključujem da se ona ondje ne nalazi. (J. J.) 
108. Lovrečica (San Lorenzo di Daila), 25. veljače 1975.

Danas popodne smo dovršili sređivanje ovoga fonda na kome je radio prof. Josip Bratulić iz Staroslavenskog instituta u Zagrebu. Građa je dobro sačuvana. Radili smo od $14^{30}$ do 18 sati. (I. G.)
Ivan Grah
Zvonimir Brumnić
J. Jelinčić

109. Kaldir, 11. ožujka 1975.

Ovaj nam fond nije dao naročitoga posla: građu smo skupili iz sakristije iz župnog stana, odvojili knjige od spisa, sredili i popisali. Radom smo započeli u 7 sati i završili u 11. Dekanatsku građu odnijeli smo da se preda novom dekanu. Od važnije građe treba napomenuti župnu kroniku. (I. G.)

Ivan Grah

A(tilije)Nefat

Jakov Jelinčić

110. Karojba, 11. ožujka 1975.

Na prvi pogled ustanovili smo da će nam ovaj fond dati mnogo posla, jer su dva fonda pomiješana, tj. Karojbu i Rakotole ${ }^{47}$, jer je glađa (!) oštećena i manjkava, jer je neposredno iza rata u župnom stanu bila smještana stanica Narodne milicije u kojem je vremenu (str. 48) bilo uništeno nešto građe, koju su upotrebljavali za paljenje vatre i jer se dio građe nalazi u rasutom stanju i poluuništena u jednom sanduku. Radili smo na dijelu građe koji se dao sređivati, odijelili knjige od spisa, a građu unutar grupa na dva fonda - Karojbu i Rakotole. Radili od 11 do $13^{30}$ i od 14 do 18 sati. (I. G.)
Ivan Grah
ANefat
Jakov Jelinčić

\section{Karojba, 18.IV 1975. (radio u Gračišću)}

Dio građe i to spisa dopremili smo u sanducima u Gračišće da ovdje možemo polako raditi, odabirati možemo polako raditi, odabirati, datirati, sređivati i popisivati. U 12 sati mučnoga rada uspio sam odvojiti i datirati spise koji su se dali obraditi. Preostao je barem jedan sanduk ostatka građe, poderane, pocijepane oko koje nema smisla dalje se truditi jer nema naročite vrijednosti. Ta je građa dospjela u takvo stanje, jer je župni stan bio u više godina prazan, a odmah iza rata nastanila se u njemu Milicija. Tako je građa propadala, bila uništavana i što se dalo spasiti spasio je domaći svećenik Ivan Bartolić. (I. G.)
J. Jelinčić
ANefat
Ivan Grah

112. Motovun, 23.4.1975.

Započeli smo radom na ovom fondu koji od starije građe ima oko 40 pergamena sve restaurirane ${ }^{48}$ te se čuvaju na Ordinarijatu u Poreču. Ostala građa dijeli se na kaptolsku,

47 Ispravno: Rakotule. (J. J.)

48 Restaurirane su u Laboratoriju za restauraciju i konzervaciju Hrvatskoga državnog arhiva (tada: Arhiv Hrvatske). (J. J.) 
dekanatsku, župsku i raznu. Danas smo uspjeli odvojiti građu na knjige i (str. 49) spise, počeli knjige dijeliti po predmetu, od spisa popisali 113 svežnjeva općih spisa. Spisi su relativno dobro sređeni do 1930. godine te je novije trebalo sređivati prije popisivanja. Ovamo spada starija građa župa Zamaska, Kaldira i Brkača. Radom smo započeli u $8^{\mathrm{s}}$ i prekinuli u 18 uz mali predah u $13^{30}$ do 14 sati (I. G.)
Ivan Grah
V(jekoslav). Sloković
J. Jelinčić

\section{Motovun, 6.5.1975.}

Danas smo uglavnom uspjeli podijeliti građu ovoga fonda, najprije knjige i spise. U ovom se fondu čuva zajedno arhivska građa kaptolskoga, dekanatskoga i samostalne kapelanije Brkač. Starija je građa bila dobro složena, ali je novija zahtjevala više posla. Nakon podijele počeli smo s popisivanjem građe. Radom smo započeli u $8^{30}$ i radili s malom pauzom do 18 sati. Kaptolska je građa oskudna, jer je većim dijelom nastradala u požaru što je 17. VII 1856. izbio u kući Stjepana Vicini-ja Ritoše kako piše u notu (?) zakladnih spisa 13,1. (Dodano): Pergamenu pronađenu iz 1648. uzeli i predali u Poreč (40) iz XI st. dalje. ${ }^{49}$ (I. G.)
Ivan Grah
V. Sloković
J. Jelinčić

\section{Motovun, 7.5.1975.}

Danas smo nastavili radom i uspjeli knjige i spise podijeliti po predmetu i građu inventarizirati. Najvažnija je građa uvedena pod Razni spisi od 13,1 do 13,20. Najstarija arhivska građa čuva se na Ordinarijatu u Pore- (str. 50) ču: to su uglavnom pergamena i jedna knjiga. Radom smo nastavili u župnom uredu u Brkaču gdje se čuva novija i tekuća građa. Radili smo od 8 do 16 sati. (I. G.)
Ivan Grah
V. Sloković
J. Jelinčić

\section{Karojba, 7.5.'75.}

Sređivali i popisivali spise i pom. knjige ž. ureda u Karojbi i Rakotulama. Od $16^{30}$ do $19^{30}$ s. (J. J.)
ANefat
J. Jelinčić

116. Karojba, 23.5.'75.

Danas smo sređivali sa sređivanjem i popisivanjem građe ž. arhiva Karojba i Rakotule. Radili smo od $9^{00}$ do 13 sati. (J. J.)
I. Grah
ANefat
J. Jelinčić

49 Brojka (40) dodana kasnije i očito se odnosi na broj pergamena (već ranije navedeno (23. 4.), dodan je i 'iz XI st. dalje' što označava stoljeće najstarije/ih pergamene/a. (J. J.) 
117. Rovinjsko selo, 10.6.'75.

Popisali arh. - registr. građe ž. ureda Rov. selo. Građa se čuva u ormaru, na suhom mjestu. Radili od $8^{30} \mathrm{~h}$ do $14^{30} \mathrm{~h}$. (J. J.)

Jakov Jelinčić

Ivan Grah

118. Motovunski Novaki, 23.6.1975.

Današnjim smo danom dovršili složiti arhivsku građu ovoga fonda, zatim smo građu popisali. Pronašli smo svežanj građe župnog fonda Kaldir. Radili od 9 do 15 sati. (I. G.)

Ivan Grah

Jakov Jelinčić

Mirko Štoković

(str. 51) 119. Žminj, 9.9.1975.

$\mathrm{Na}$ ovom smo fondu radili 5.3.1972. (vidi br. 42, str. 17), ali je nedavno bio pronađen još jedan sanduk sakrivene građe koju smo morali najprije sortirati, složiti i onda popisati. Od spisa ima najviše općih, pa računskih, a manje ženidbenih i raznih. Ima i prilično pomoćnih knjiga. Tako smo trebali ponovo pisati inventar u koji će ranije popisana građa doći na svoje mjesto predmetno i kronološki. Radom započeli u 9 sati i prekinuli u 18. (I. G.)

J. Jelinčić

Ivan Grah

120. Žminj, 10.9.1975.

Danas se nastavilo i završilo s radom popisivanja fonda: trebalo je još složiti računske i razne spise onda preći na inventarizaciju uključivši i ranije popisanu noviju građu. Radio Jakov Jelinčić od 8 do 14 sati i 11.9.1975 od 7 do 10 sati (I. G.)

J. Jelinčić

Ivan Grah

121. Sv. Petar u Šumi, 6.10.1975. (Vidi br. 53 str. 22)

Danas smo kompletirali ovaj fond pošto je veća količina građe pretežno spisa bila pronađena ove godine na tavanu župnoga stana. Uglavnom je starija građa. Nekoliko smo knjiga uvrstili u raniji popis, ali smo spise morali nanovo numerirati. Pronađene su i dvije knjige okružnica u koje su uvedeni domaći događaji i zbivanja. Radili od $8^{30}$ do 18 sati uz mali prekid. (I. G.)

\section{J. Jelinčić}

Ivan Grah

(str. 52) 122. Pula, Katedrala, 20.10.1975.

Započeli smo radom na sređivanju i popisivanju fondova koji se čuvaju u katedralnom arhivu. Na prvi pogled ustanovili smo da se radi o župnom fondu Pula gdje je koncentrirana sva starija građa, zatim o austro-ugarskom mornaričkom fondu (Marine Pfarrant) i o dekanatskom fondu. Građa je pohranjena u velikom ormaru u hodniku, zatim u manje ormare i policu u predsoblju sakristije, a novija se građa čuva u župnom uredu u istoj zgradi 
na drugom katu. Danas smo odijelili knjige od spisa, ali samo djelomično. Radili smo od 8 do 19 sati. Posjetio nas je prof. Bertoša i mons. Bogetić. (I. G.)
Jakov Jelinčić
Ivan Grah

\section{Pula, Katedrala, 21.10.1975.}

Danas smo nastavili radom, uspjeli popisati knjige župnog fonda, kaptolskog i dekanatskog, zatim smo sredili i popisali ženidbene spise (176 svežnjeva), sredili kaptolske, računske i nešto raznih. Radili od 8 do 20 sati. (I. G.)
Jakov Jelinčić
Ivan Grah

124. Ližnjan, 29. listopada 1975.

Građa ovog je arhiva relativno bila dobro sređena. Radi se zapravo o dva fonda tj. Ližnjana i Šišana. Ima vrijedne građe kao mat. knjige, knjige okružnica, vlastoručna pisma hrvatski ${ }^{50}$ biskupa Dobrile. Spisa ima 35 svežnjeva. Radom smo započeli u 8 sati (str. 53) i radili do 11 sati. (I. G.)

Jakov Jelinčić $\quad$ Ivan Grah

125. Šišan, 29. listopada 1975.

Radom smo nastavili na kompletiranju ovoga fonda jer se dijelom građa nalazila $u$ Ližnjanu i dijelom u Šišanu. Sada se nalazi kompletirana u župnom stanu u Ližnjanu. Međutim spisa ima vrlo malo i to pretežno ženidbenih. Općih spisa uopće nema. Ima i starijih knjiga; Šišan je u svoje vrijeme imao kaptol, zatim bio nadžupa. Radili smo od 11 do 15 sati uz mali prekid. (I. G.) Jakov navečer od 20 do 22 sata radio na fondu Šišana. (dodao J. J.)

Jakov Jelinčić Ivan Grah

126. Medulin, 29. listopada 1975.

Ovaj je fond dobro sačuvan i sređen te nam nije dao mnogo posla. Spisa ima 43 svežnja. Od matičnih knjiga oduzete su najstarije koje se čuvaju u Hist. arhivu u Pazinu, i novije koje se nalaze u matičnom uredu u Puli. Radom smo započeli u 15 i radili do 18 sati. U radu pomagao domaći župnik Ante Močibob. (I. G.)
J. Jelinčić
Ante Močibob
Ivan Grah

127. Pomer, 30. listopada 1975.

Ujutro nastavili sa fondom ž. u. u Pomeru. Fond djelomično sačuvan. Radili od 8 do 12 uz pomoć župnika Ante Močiboba. (J. J.)

Ivan Grah Ante Močibob J. Jelinčić

50 Točnije, pisama na hrvatskom jeziku. (J. J.) 
(str. 54) 128. Premantura, 5.11.1975.

Danas smo se otisnuli na najjužniju župu Istre, u Premanturu gdje smo popisali arhivsku građu. Građa je bila već ranije prilično sređena. Matične knjige sižu do 1623. godine. Radili od 7 do 12. (I. G.)

J. Jelinčić

Ivan Grah

129. Pula, Katedrala, 5. studenoga 1975.

Danas smo nastavili radom na fondovima koji se čuvaju na ovom mjestu. Radili smo na knjigama Mornaričke župe i na spisima dekanatskog fonda, kaptolskog i župnog. Uspjeli smo završiti i popisati dekanatski fond. Od kaptolske građe koja je vrlo oskudna ima nešto vrijednije građe barem na prvi pogled. Veći se dio te građe nalazi u Hist. arhivu u Pazinu i u Rijeci kamo je dospjela silom prilika iza ratnih događaja. Glavnina je građe stradala u prošlosti od požara prema bilješkama u samom arhivu i u literaturi. Radili smo od 13 do 20 sati. (I. G.)

J. Jelinčić

Ivan Grah

130. Pula, Katedrala, 6. studenoga 1975.

Današnjim radom uspjeli smo inventarizirati građu kaptolskog fonda, zatim vikarijatskog i nastavili radom na mornaričkom fondu tj. na opširnoj građi koja je ostala kao plod dušobrižništva mornaričkog garnizona austro-ugarske monarhije. Ovaj nam je fond zadao mnogo brige zbog jezika i pisma goticom. Samih spisa ima (str. 55) oko 300 svežnjeva. Najstariji spis kaptolskog fonda nosi datum 1585. Radili smo u ne najboljim uvjetima od 7 do 19 sati, ali nismo uspjeli završiti. (I. G.)
J. Jelinčić
Ivan Grah

131. Pula, Katedrala, 13.11. 1975.

Današnjim smo radom konačno uspjeli završiti s popisivanjem građe fonda mornaričke crkve. Radili od 8 do 13 sati. Pronašli smo revers o deponiranoj građi. (I. G.)
J. Jelinčić
Ivan Grah

\section{Loborika, 13.11.1975.}

Od arhivske građe ovoga fonda sačuvale su se pretežno knjige i svega jedan svežanj starijih spisa. U dekanatskom fondu u Puli ima jedan svežanj spisa i dopisa Loborike. Spisi ovoga fonda propali su neposredno nakon II svijetskog rata kada je župna kuća bila u korištenju seljačke zadruge. Radili od 14 do 16 sati. Građa se čuva u župnoj kući u Marčani. (I. G.)
J. Jelinčić
D. Domšićc ${ }^{51}$
Ivan Grah

${ }^{51}$ Župnik Dragan Domšić. 
133. Marčana, 13.11.1975.

Nastavili smo na sređivanju građe ovoga fonda. Građe je bila već ranije sređena te nam nije zadala mnogo brige. Župa je novijega datuma tj. od 1912. jer je ranije bila u sastavu župe Motvoran. Radili od 16 do 20 sati.
J. Jelinčić
DDomšić
Ivan Grah

(str. 56) 134. Muntić kod Pule, 14.11.1975.

Dio građe ovoga fonda donijeli smo iz Marčane te će vjerojatno tamo biti još nešto građe pomiješane s onim fondom. Ovaj fond ima vrlo malo građe koja se čuva u župnom stanu u Valturi. Radili od 7 do 9 sati uz pomoć župnika Staver Željka (I. G.)
J. Jelinčić
Željko Staver
Ivan Grah

135. Valtura, 14.11.1975.

Nastavili smo raditi na fondu ove župe koji je bogatiji i u knjigama i u spisima. Vjerojatno ima još građe ovoga fonda i u Marčani odakle smo vratili jednu matičnu knjigu umrlih iz XVIII stoljeća. Spisi sežu u XVII stoljeće. Prema tragovima izgleda da je dio starije građe tj. iz XVII i XVIII stoljeća stradao od požara. Preostala je građa dobro čuvana a bila je dosta dobro sređena. Radili smo uz pomoć župnika g. Staver Željka od 9 do 13 sati. (I. G.)
J. Jelinčić
Željko Staver
Ivan Grah

136. Fažana, 14.11.1975.

Građa ovoga fonda prošla je kroz procijep (!) za i iza drugog rata, više puta bila prebacivana iz kuće u kuću kad je župnik morao seliti po višoj sili. Sada je konačno župnik g. Valentin Cukarić preostalu skupi (!) u župnom stanu gdje smo je sredili i popisali. Ima vrijedne građe (str. 57) ali je manjkava. Radili smo od 14 do 18 sati uz pomoć župnika. (I. G.)

J. Jelinčić

Val. Cukarić

Ivan Grah

137. Štinjan, 14. studenoga 1975.

I građa ovog fonda imala je svoju burnu prošlost, pa je djelomično i propala, djelomično oštećena. Spise nije bilo moguće kronološki podijeliti jer su gotovo u rasutom stanju. Uz pomoć g. župnika iz Fažane radili smo od $18^{30}$ do 21 sat. (I. G.)
J. Jelinčić
Val. Cukarić
Ivan Grah 
138. Rakalj, 18. studenoga 1975.

Došli smo do Rakalja ${ }^{52}$ po krasnom vremenu ali po vrlo lošoj cesti, građu fonda našli sređenu ali samo kronološki. Spise smo tako i ostavili tj. zajedno opće, ženidbene i računske, jer i tako fond nije velik. U ovom župnom stanu čuva se dio građe iz Krnice. Radili od 8 do 11 sati uz pomoć župnika Sinožić Petra. (I. G.)

\section{J. Jelinčić}

Ivan Grah

\section{Krnica, 18.11.1975.}

Radom smo nastavili na dijelu fonda Krnice koji se čuva u Raklju, ima nešto starije građe i sva novija tj. od 1951. dalje. Zatim smo prešli u Krnicu gdje se u sakristiji župne crkve, čuva preostala građa fonda Krnice, Motvarana i Kavrana. Neposredno (str. 58) iza 1945. godine župnik je bio formalno istjeran iz župnoga stana kao općinske zgrade i uselila Milicija i mjesni ured. U to je vrijeme mnogo građe upropašteno. Sređivanje građe zadalo nam je brige, jer je bilo teško podijeliti pogotovo knjige na fondove. Motvoran je bila nadžupa, a područne su joj bile crkve Kavrana i Marčane. Krnica se uopće ne spominje u starijim šematizmima 1842, 1847, dok je spominje Petronio ${ }^{53}$ na str. 291. Krnicu ne spominje kao posebnu župu ni šematizam od 1924. A najnoviji šematizam BKJ iz 1975 ne spominje Motvoran nego Krnicu. Spise smo zatekli kronološki povezane, ali ne i predmetno, pa smo tako i ostavili ih, jedino što smo najstarije mat. knjige izvadili i uvrstili ih u knjige. Knjige smo podijelili na tri fonda: Motvoran, Krnicu i Kavran. Radili smo od 11 do 13 i od 14 do 20 sati. (I. G.)

J. Jelinčić

Ivan Grah

140. Kavran, 20.11.1975.

Novija se građa čuva u župnom stanu u Valturi, dio starije pretežno knjige, čuvaju se u sakristiji župne crkve u Krnici, dok su spisi kronološki poredani u Krničkom fondu. Radili smo oko 3 sata. Usput uzeli građu iz Filipane, knjige ostavili u župnom stanu u Hreljićima, a spise u rasutom stanju uzeli u Gračišće za sređivanje jer je bilo nemoguće tamo raditi. Pomagali sveć. Petar Sinožić i Stjepan Cvitić. (I. G.)
J. Jelinčić
Ivan Grah

(str. 59) 141. Filipana (radio u Gračišću) 20.11.1975.

Ostatak građe ovog fonda našli smo u vrlo lošem stanju te je bilo nemoguće raditi kod tvorca fonda. Građu smo dopremili u Gračišće gdje sam morao spise pregledati, datirati, srediti kronološki i uvezati u svežnjeve. Ima jedno polemičko pismo s kanonikom Stankovićem i pismo pisano hrvatski još 1828. godine. Na fondu sam radio 8 sati. Nastavili smo

52 Trebalo bi stajati: Raklja jer se radi o nepostojanom $a$. (J. J.)

53 Radi se o knjizi Delle Memorie dell'Istria sacre, e profane con la più esatta topografia ò sia descritione dei luoghi, che sino hora si habbia veduto. Il tutto trattato dalli scritti dell'eruditissimo monsignor Gia. Filippo Tomasini fù vescovo di C.N. (Cittanova - J. J.) etc parte seconda, MDCLXXXI 1 Agosto (J. J.) 
na kompletiranju fonda i izvršili popis građe u župnom stanu u Hreljićima (Majka Božja od Zdravlja). Radili od 8 do 12 sati. (I. G.)
J. Jelinčić
Stjepan Cvitić
Ivan Grah

142. Hreljići, 26.11.1975.

Ovo je samostalna kapelanija novijega datuma, prema tome starija se građa čuva u Barbanu. Matične knjige datiraju od 1960. godine. (I. G.)
J. Jelinčić
Cvitić Stjepan
Ivan Grah

\section{Barban, 26.XI 1975.}

Na ovom smo fondu radili još 1971. godine u Pazinu u sjemeništu gdje je veći dio građe pohranjen. U sjedištu se čuvaju starije knjige, a od spisa pretežno novija. Inventar smo kompletirali. Trebat će građu iz Pazina dopremiti u Barban i sam fond kompletirati. Radili od 13 do 20 sati uz pomoć župnika. (I. G.)
J. Jelinčić
A(ntun)Kurelović
Ivan Grah

\section{(1976. godina) $)^{54}$}

(str. 60) 144. Vodnjan, 20.10.1976.

Nakon duge stanke ${ }^{55}$ danas smo nastavili radom na sređivanju ovog arhiva. ${ }^{56}$ Što se tiče spisa nije bilo puno posla zahvaljujući ranijem župniku pok. Pereša Vinku koji je izvršio detaljan popis građe, opisao svaku jedinicu spisa, a knjige je samo naveo. Spisi pripadaju župnom i dekanatskom fondu: nažalost ima ih malo i ako najstariji datira na 1575. godinu. Prema količini knjiga fond je morao biti vrlo bogat: matične knjige datiraju od Tridentinuma. ${ }^{57}$ Bilo je i tridesetak bratovština. Knjige smo podijelili na kaptolske, župne i dekanatske. Radom smo započeli u 10 sati i prekinuli u 21 sat. (I. G.)

Jakov Jelinčić

Ivan Grah

145. Vodnjan, 25.10.1976.

Nastavio sa sređivanjem. Završio sam sa sređivanjem i popisivanjem župnog arhiva, a zatim kaptolskog, te na kraju dekanatskog. Radom započeo u $18^{\mathrm{h}}$, a završio u $23^{40}$. (J. J.)

Jakov Jelinčić

\footnotetext{
Dodao J. J.

55 Stanka je nastupila zbog prezauzetosti poslom u Arhivu i pripremama za obranu magistarskoga rada Jakova Jelinčića (veljača 1977.). (J. J.)

56 Ne sjećam se da smo ga ranije počeli sređivati. Mislim da je to bio početak rada na ovom fondu. (J. J.)

57 Tridentski sabor (1545. - 1563.) donio je 11. studenoga 1563. odredbu o vođenju matičnih knjiga. (J. J.)
} 
146. Šumber, 27.10.1976.

Dio građe ovoga fonda nalazi se u Šumberu, a dio pretežno novija građa (str. 61) i tekuće knjige u župnom uredu Svate Nedjelje. Građa je manjkava i prijeti joj vlaga. Radili smo uz pomoć župnika vlč. Petrović Aleksandra od 9 do 12 sat. (I. G.)

Jakov Jelinčić

Ivan Grah

147. Sveta Nedjelja Labinska, 27.10.1976.

Građa je ovoga fonda prilično dobro sačuvana i sređena. Spisi se čuvaju u zidnom ormaru a knjige u župnom uredu. Radili smo najprije na odvajanju fondova novije građe - Sv. Nedjelja, Sveti Martin i Šumber. Radili smo od 13 do 18 sati. Zatim smo išli pregledati dio fonda Svetoga Martina koji čuva u samom sjedištu. Tamo smo uspjeli kompletirati knjige, ali je bilo nemoguće išta učiniti sa spisima. Dogovorili smo se sa župnikom da ih autom dopremi u Gračišće gdje ću moći polako sređivati ih. Radili od 18 do 20 sati.

Jakov Jelinčić

Ivan Grah

\section{Labin, 17. studenoga 1976.}

Danas smo se dali na posao sređivanja građe ovih fondova: postoji kaptolski, dekanatski i župni fond. Na popisivanju građe tih fondova radili su pred više go- (str. 62) (!) gosp. biskup. dr Dragutin Nežić i prof. Miroslav Sironić kad je građa bila deponirana u sjemeništu u Pazinu zbog opasnosti rušenja Labina ${ }^{58}$. Tako složena građa nakon prošle opasnosti od rušenja grada bila je vraćena u sjedište 1971. godine. Iako su sređivači posvetili mnogo truda i rada kod sređivanja, ipak nismo mogli prihvatiti njihov inventar jer građa nije bila podijeljena posvema ni po fondovima, a da se ne govori po predmetu unutar fonda. Zatim dio kaptolske građe nije bio uveden u taj inventar. Ovi su fondovi bogati građom ne u (!) toliko u količini koliko u kvaliteti. Građa siže do u XV stoljeće. Prvim danom rada nismo uspjeli ni fondove podijeliti i ako smo radili gotovo neprekidno od 8 do 22 sata. (I. G.)

Jakov Jelinčić

Ivan Grah

149. Labin, 22.11.1976.

Nastavili smo s radom na lučenju fondova: sa spisima nije bilo naročitih poteškoća tako da smo uspjeli popisati fond dekanatski i župni dok s kaptolskim moramo čekati da se popišu knjige kaptolskoga fonda. Kaptolski fond zadaje prilične teškoće pored lumbaga koji muči Jakova. Mnogo ima knjiga dnevnih računa i to raznih. Radili smo: Jakov od 8 do 22s, Ivan Grah od 13 do 22s. (I. G.)

Jakov Jelinčić

Ivan Grah

58 Radilo se, koliko se sjećam, o opasnosti od tzv. 'gorskog udara'. (J. J.) 
(str. 63) 150. Labin, 23.11.1976.

Danas smo nastavili radom na sređivanju knjiga kaptolskog i župnog fonda. Posao smo dobro obavili: počeli s inventariziranjem knjiga župnog fonda dok je kaptolski bio podijeljen po predmetima. Radili smo od 8 do 15 sati. (I. G.)

Jakov Jelinčić

Ivan Grah

151. Labin, 9.12.1976.

Ni danas nismo uspjeli sastaviti sve inventare: pabirčenjem građe u župnom uredu Podlabin i Marcilnica uspjeli smo kompletirati dekanatski i župni fond. Zbog dizmembracije $^{59}$ župa 1960. nastale su poteškoće u formiranju i vođenju matičnih knjiga tekućih: izgleda da pitanje nije s arhivističke strane najpovoljnije riješeno! Od kaptolskog fonda koji je bogat kvalitetom uspjeli smo odijeliti knjige po grupama i spise srediti predmetno i kronološki. Uspjeli smo popisati spise i dio knjiga ovog fonda. Radili smo od 8 do 22 sata i zbog premorenosti prekinuli radom. (I. G.)

Jakov Jelinčić

Ivan Grah

152. Labin, 11.12.1976.

$\mathrm{Na}$ inventariziranju knjiga kaptolskog fonda radio je danas samo prof. Jakov Jelinčić i konačno uspio s popisivanjem ovoga fonda. Tre- (str. 64) ba napomenuti da ovaj kaptolski fond ima mnogo raznih knjiga, često i manjkavih, oštećenih što je sve zadalo većih poteškoća i briga kod sređivanja. radio je od 9 do 24 sata! (I. G.)

Jakov Jelinčić

\section{(1977. godina) $)^{60}$}

153. Raša, 11.10.1977.

Danas smo popisali arhivsku građu ovoga fonda: župa je bila osnovana 1938. dizmembracijom Labinske župe. Stariji su spisi i knjige u Labinu. Radili smo od 8 do 10 sati. Građe ima malo. (I. G.)

Ivan Grah Marijan Milovan Jakov Jelinčić

154. Koromačno, 11.10.1977.

Posjetili Koromačno. Župnik Jakov Miličić bio obaviješten, ali je hitno morao otputovati. Popisivanje odgođeno do daljnjega. (J. J.)

59 Ispravno: dismembracija - od latinskoga dismembratio: komadanje, raščlanjivanje; izdvajanje crkvene općine iz njene dosadašnje župe. Šime ANIĆ - Nikola KLAIĆ - Želimir DOMOVIĆ, Rječnik stranih riječi, SANI-PLUS, Zagreb, 1999., str. 309. (J. J.)

60

Dodao J. J. 
155. Sveta Nedjelja Labinska, 11.10.1977.

Završili sa sređivanjem (osnovnim) i popisom građe župnog ureda Sveti Martin Labinski (Martinski). Radili od 12 do 19 sati. (Vidi izvještaj od 27.10.'76.) (J. J.)

Ivan Grah

Jakov Jelinčić

(str. 65) 156. Sveti Lovreč-Diminići i Sveta Lucija Škitača, 17.11.1977.

Ovaj je fond oskudan građom, koja je bila uništena kroz ranije razdoblje, kad je u župnom stanu bila kasarna austrijskih žandara i talijanskih karabiniera. Dva su zapravo fonda, koja smo podijelili, spise složili u svežnjeve i popisali uz pomoć domaćega župnika Miličić Jakova. Radili smo od 13 do 19 sati. Najstariji spisi Sv. Lovreča odnose se na Pomer i okolicu. (I. G.)

Ivan Grah

Miličić Jakov

Jakov Jelinčić

\section{(1978. godina) ${ }^{61}$}

157. Galižana, 14.9.1978. i 20.8.1978. ${ }^{62}$

Radio na sređivanju građe ovoga fonda sam prof. Jakov Jelinčić u dva navrata po šest sati. Građe ima malo i manjkava je. (I. G.)

Ivan Grah

158. Savičenta, 15.9.1979. i 19.9.1979.

U par smo navrata posjetili i pregledali ovaj fond. Građa je prividno sređena. Zaključili smo da je spremimo u sanduke i dopremimo u Gračišće gdje ćemo je moći srediti, popisati i onda vratiti. Taj je posao obavio prof. Jelinčić Jakov i svojim autom dovezao u Gračišće. Radio je 8 sati u dva navrata. (I. G.)

Ivan Grah

(1979. godina) $)^{63}$

(str. 66) 159. Savičenta (u Gračišću), 20. i 27.9.1979.

U odvajanju građe fonda župnog ureda Savičente radio prof. Jakov Jelinčić u dva navrata po 5 sati. Kako izgleda građa je samo prividno bila izgledala (!) sređena. (I. G.)

Ivan Grah

\footnotetext{
61 Dodao J. J.

62 Treba biti: 20. 8. 1978. i 14. 9. 1978. (J. J.)

63 Dodao J. J.
} 
160. Savičenta (u Gračišću), 28. i 30.9.1979.

Na evidentiranju i sortiranju knjiga radio je prof. Jakov Jelinčić dva puta po 5 sati. Ivan Grah počeo radom 3.9. na sređivanju spisa. Kako izgleda bit će mnogo više posla od predviđenoga. (I. G.)

Ivan Grah

161. Savičenta (u Gračišću), 25. i 28.10.1979.

Danas smo radili i obrađivali svaki svoj dio građe: grupiranje knjiga i spisa po predmetu. Radili smo od 15 do 20 sati u dva navrata. (I. G.)

Ivan Grah

162. Savičenta (u Gračišću), 6.11.1979.

Danas smo radili na odvajanju građe i formiranju grupa i uspjeli grupirati građu. Radili smo: prof. Jakov od 9 do 15 sati, Ivan Grah od 9 do (str. 67) 22 sata. Trebalo je zaviriti u sve knjige i gotovo u sve svežnjeve spisa. Građa još nije gotova za inventariziranje. (I. G.)

Ivan Grah

163. Savičenta (u Gračišću), 7.11.1979.

Danas smo nastavili radom i konačno uspjeli srediti građu po grupama. Radili smo: prof. Jakov od 9 do 15 sati, a Ivan Grah od 9 do 23 sata u noći. Stariji spisi bili su pomješani i po predmetu i po godinama. Stoga je trebalo više truda i vremena da se barem donekle srede. (I. G.)

Ivan Grah

\section{Savičenta (u Gračišću), 8.11.1979.}

Danas smo radili jedan na popisivanju knjiga drugi na formiranju i veživanju (!) svežnjeva spisa. Radom smo započeli u 10 sati i radili do 18 sati. (I. G.)

Ivan Grah

165. Savičenta (u Gračišću), 19. i 13.11.1979.

Prvi smo dan radili od 13 do 19 sati, drugi od 15 do 19 i uspjeli svršiti sa sređivanjem, veživanjem spisa i popisivanjem. Građa će prvom prigodom biti odvežena (!) u Savičentu gdje se uređuje župna kuća stradala od požara. Ima vrijedne građe. Od spisa (str. 68) treba spomenuti najstarije svežnjeve koji datiraju od 1661. godine, zatim one koji su zavedeni pod „Razno“ i neki svežnjevi u računskim spisima. Knjige datiraju od XVI st. dalje. Ovaj je arhivski fond malo korišten do sada, ali nije čudno kad nije bio sređen i kad nije bilo inventara. Djelomično se koristio domaći svećenik Ivan Milovan kod sastavljanja male monografije „Savičenta jučer i danas“, Pula 1895. Građa je manjkava i u knjigama i u spisima. 


\section{0. (godina) $)^{64}$}

166. Dolenja Vas, 21.10.1980.

Danas smo radili na odvajanju fondova građe Dolenjevasi (!), Vranje i Boljuna, Građa Vranje do 1943. uništena je za vrijeme rata, kad su Njemci spalili župni stan. Starije je građe malo ostalo. Fond Dolenje Vasi bogat je naročito matičnim knjigama. Uspjeli smo srediti i popisati knjige i spise Dolenje Vasi. Usput smo posjetili fond (!) Boljuna, odvojili knjige od spisa, ali kad je trebalo popisati građu otkrili smo da na tavanu ima još hrpa spisa, koju je, navodno župnik Vecchiet bio sklonio za vrijeme rata da ih spasi od fašista i Njemaca. Njemci su žup- (str. 69) nika odveli u logor u Dachau gdje je umro. Od ovoga smo fonda popisali samo knjige, dok smo spise ostavili za drugi put. Radili smo od 8 do 22 sata. (I. G.)

Ivan Grah

B. Milanović ${ }^{65}$ župnik

167. Boljun, na Šimunju 28.10.1980.

Danas smo nastavili radom na sređivanju i na popisivanju pronađene građe na tavanu župne kuće. Ugodno smo se iznenadili kad smo ustanovili da gotovo pola građe pripada fondu župnog ureda Vranje, za koju se mislilo da je bila spaljena zajedno sa župnim stanom 1943. Netko je ranije bio dopremio spise do 1927. godine u Boljun te su tako izbjegli uništenju. Manjkavi su spisi od 1930. dalje. Radom smo započeli u 8 sati i završili u 13. Iz Boljuna smo odvezli građu Vranje u Dolenju Vas da kompletiramo fond. Ima vrijedne građe. (I. G.)

Ivan Grah

168. Dolenja Vas, na Šimunju 28.10.1980.

Ovdje smo nastavili radom u 14 sati i radili bez prekida do 21 sat. Napornim radom uspjeli smo kompletirati fond Vranjske župe, srediti ga i inventarizirati. U ovome fondu ima i građe koja se odnosi na područnu crkvicu Brest (Kraljevski). Administracija župe bila je dobro vođena, ima vrijedne građe. Točno su vođena urbarijalna podavanja u sitnoj stoci i plodovi- (str. 70) ma te se tako može pratiti razvoj stočarstva i zemljoradnje barem od oko 1800. do 1850. godine. Radom nam je pomagao i župnik. (I. G.)

Ivan Grah

64 Dodao J. J.

65 Radi se o Boži Milanoviću 'mlađem', i danas živom gotovo stogodišnjaku. (J. J.) 


\section{KAZALO}

Bačva, 6.3.1974. (I. G. - $1^{30}$ s.; J. J. - $1^{30}$ s.), br. 82 (str. 35)

Baderna, 26.2.1974. (I. G. - 6 s.; J. J. - 6 s.), br. 76 (str. 33)

Bale, 8.11.1972. (I. G. - 12 s.; J. J. - 12 s.), br. 50 (str. 20/2166)

Barban, 22., 27. i 30.4.; 7.5.; 22. i 23.6.1971. te 26.11.1975. (I. G. - $21^{30}$ J. J. - 39 s.; G. P. - 6 s.), br. 11-16 i 143 (str. 5-7 i 59)

Beram, 8.3.1972. (I. G. - 6 s.), br. 40 (str. 15)

Boljun, 28.10.1980. (I. G. - 5 s.; J. J. - 5 s.), br. 167 (str. $/ 69 /{ }^{/ 67}$ )

Brest, 28.8.1973. (I. G. - 1 s.; J. J. - 1 s.), br. 60 (str. 25)

Brtonigla, 27.11.1973. (I. G. - 7 s.; J. J. - 7 s.), br. 73 (str. 30/31)

Buzet, 21. i 28.2.1973. (I. G. - 15 s.; J. J. - 15 s.), br. 54 i 55 (str. 23)

Cere (Sv. Matej), 9.3.1972. (I. G. - 1 s.; J. J. - 1 s.), br. 41 (str. 15)

Cerovlje, 15.4. i 7.10.1971. (I. G. - 2 s.; J. J. - 1 s.), br. $10 \mathrm{a}^{68}$ i 17 (str. 5 i 7 )

Čepić kod Kršana, 23.2.1972. i 2.9.1974. (I. G. - 1 s.; J. J. - 445 s.), br. 37 i 104 (str. 15 i 45)

Dolenja Vas, 21. i 28.10.1980. (I. G. - 14; J. J. - 14), br. 166 (str. 68-69)

Fažana, 14.11.1975. (I. G. - 4 s.; J. J. - 4 s.), br. 136 (str. 56/57)

Filipana, 20.11.1975. (I. G. - 12 s.; J. J. - 4 s.), br. 141 (str. 59)

Funtana, 20.2.1974. (I. G. - 2 s.; J. J. - 2 s.), br. 75 (str. 22/23)

Fuškulin, 25.7.1974. (I. G. - 9 s.; J. J. - 9 s.), br. 101 (str. 43)

Galižana, 20.8. i 14.9.1978. (J. J. - 12 s.), br. 157 (str. 65)

Gračišće, 18. i 22.12.1970. i 8.1.1971. (I. G. - 20 s.; J. J. - 20 s.), br. 1-3 (str. 1 i 2)

Gradina kod Poreča, 27.8.1974. (I. G. - $4^{30}$ s.), br. 103 (str. 44)

Grdoselo, 8.2.1973. (I. G. - 7 s.; J. J. - 7 s.), br. 52 (str. 22)

Grimalda, 28.5.1974. (I. G. - $3^{30}$ s.; J. J. - $3^{30}$ s.), br. 93 (str. 40/41)

Grožnjan, 24.10.1973. (I. G. - 5 s.; J. J. - 5 s.), br. 69 (str. 29)

Hreljići, 26.11.1975. (građa se čuva u Barbanu), br. 142 (str. 59)

Hum, 28.8.1973. (I. G. - $4^{30}$ s.; J. J. - $4^{30}$ s.), br. 62 (str. 26)

Kaldir, 11.3.1975. (I. G. - 4 s.; J. J. - 4 s.), br. 109 (str. 47)

Kanfanar, 16.11.1972. (I. G. - 8 s.; J. J. - 8 s.), br. 51 (str. 21)

Karojba, 11.3., 18.4. te 7. i 23.5.1975. (I. G. - 21 s.; J. J. - 9 s.), br. 110, 111, 115 i 116 (str. $47 / 48$ i 50$)$

Kašćerga, 14.3.1972. (I. G. - $2^{30}$ s.; J. J. - $2^{30}$ s.), br. 43 (str. 17)

\footnotetext{
66 Ako se tekst izvješća o radu na pojedinom fondu nalazi na dvjema stranicama, njih odvajamo kosom crtom.

67 Broj između dvije kose crte označava stranicu koja u izvorniku nije označena. (J. J.)

68 Zajedno kapelanija Borut i crkva u Previžu.
} 
Kaštel, 16.5.1974. (I. G. - 5 s.; J. J. - 5 s.), br. 91 (str. 39)

Kavran, 20.11.1975. (I. G. - 3 s.; J. J. - 3 s.), br. 140 (str. 58)

Kostanjica, 24.10.1973. (I. G. - 3 s.; J. J. - 3 s.), br. 70 (str. 29)

Kožljak, 1.9.1973. i 2.9.1974. (I. G. - 3 s.; J. J. - 2 s.), br. 67 (str. 29)

Kringa, 12.4.1972. 14.3.1972. (I. G. - 10 s.; J. J. - 10 s.), br. 44 (str. 18)

Krnica, 18.11.1975. (I. G. - 8 s.; J. J. - 8 s.), br. 139 (str. 57/58)

Kršan, 1.9.1973. (I. G. - 10 s.; J. J. - 10 s.), br. 65 i 66 (str. 27/28)

Kršikla, 30.5. i 2.9.1974. (I. G. - 4 s.), br. 95 (str. 40 i 45)

Labin, 17., 22. i 23.11. te 9. i 11.12.1976. (I. G. - 40; J. J. - 58), br. 147-152 (str. 61-64)

Lanišće, 27.8.1973. (I. G. - 14 s.; J. J. - 14 s.), br. 59 (str. 25)

Ližnjan, 29.10.1975. (I. G. - 3 s.; J. J. - 3 s.), br. 124 (str. 52/53)

Lindar, 26.3.1971. (I. G. - 9 s.; J. J. - $8^{30}$ s.), br. 9 (str. 4)

Loborika, 13.11.1975. (I. G. - 2 s.; J. J. - 2 s.), br. 132 (str. 55)

Lovrečica (San Lorenzo di Daila), 25.2.1975. (I. G. - $3^{30}$ s.; J. J. - $3^{30}$ s.), br. 108 (str. 47)

Marčana, 13.11.1975. (I. G. - 4 s.; J. J. - 4 s.), br. 133 (str. 55)

Materada, 25.10.1973. (I. G. - 10 s.; J. J. - 10 s.), br. 72 (str. 30)

Medulin, 29.10.1975. (I. G. - 3 s.; J. J. - 3 s.), br. 126 (str. 53)

Motovun, 23.4.; 6. i 7.5.1975. (I. G. - 27 s.; J. J. - 27 s.), br. 112-114 (str. 48-50)

Motovunski Novaki, 23.6.1975. (I. G. - 6 s.; J. J. - 6 s.), br. 118 (str. 50)

Muntić kod Pule, 14.11.1975. (I. G. - 2 s.; J. J. - 2 s.), br. 134 (str. 56)

Muntrilj, 26.2.1974. (I. G. - 1 s.; J. J. - 1 s.), br. 78 (str. 33/34)

Nova Vas Novigradska (I. G. - 3 s.; J. J. - 3 s.), br. 73 (str. 30/31)

Nova Vas Porečka, 6. i 14.3.; 26.4. i 6.5.1974. (I. G. - 25 s.; J. J. - 2 s.), br. 83, 85, 88 i 89 (str. 36-38)

Oprtalj, 3.5.1972. (I. G. - $10^{30}$ s.; J. J. - $10^{30}$ s.), br. 45 (str. 18/19)

Paz, 24.7.1974. (I. G. - 4 s.), br. 100 (str. 43)

Pazin, 7., 8., 11. i 15.10.1971. (I. G. - 22 s.; J. J. - 16 s.), br. 17-20 (str. 7-9)

Pazinski Novaki, 22.4. i 22.10.1971. (I. G. - 40 s.), br. 10 a, 11-16 (str. 5-7) i 22 (str. 9)

Pićan, 15., 16., 25. i 26. 2. i 1.3.1971. (I. G. - 39 s.; J. J. - 41 s.), br. 4-8 (str. 2-4)

Plomin, 10.10.1973. (I. G. - 12 s.; J. J. - 12 s.), br. 68 (str. 28/29)

Pomer, 30.10.1975. (I. G. - 4 s.; J. J. - 4 s.), br. 127 (str. 53)

Poreč, 12. i 20.6.; 2. i 25.7. te 27.8.1974. (I. G. - $54^{30}$ s.; J. J. - $43^{30}$ s.), br. $96-99$ te $101 \mathrm{i}$ 102 (str. 40-44)

Premantura, 5.11.1975. (I. G. - 5 s.; J. J. - 5 s.), br. 128 (str. 54) 
Pula, 20. i 21.10.; 5., 6. i 13.11.1975. (I. G. - 47; J. J. - 47), br. 122, 123, 129-131 (str. 52, 54 i 55)

Račice, 1.3.1973. (I. G. - 4 s.; J. J. - 4 s.), br. 58 (str. 24)

Rakalj, 18.11.1975. (I. G. - 3 s.; J. J. - 3 s.), br. 138 (str. 57)

Rakotule, 7.5.1975. (I. G. - 3 s.; J. J. - 3 s.), br. 115 (str. 50)

Raša, 11.10.1977. (I. G. - 2 s.; J. J. - 2 s.), br. 53 (str. 64)

Roč, 28. i 29.8.1973. (I. G. - $13^{30}$ s.; J. J. - $13^{30}$ s.), br. 63 i 64 (str. 26 i 27)

Rovinj, 25., 26., 27. i 29.10.; 3., 5., 6. 8., 12., 15. i 23.11.1971. i 23.2.1972. (I. G. - 70 s; J.

J. 75 s.; J. L. - 9 s.), br. 23-33 i 38 (str. 10-13 i 15)

Rovinjsko Selo, 10.6.1975. (I. G. - 6 s.; J. J. - 6 s.), br. 117 (str. 50)

Savičenta (Svetvinčenat), 15., 19., 20., 27., 28. i 30.9.; 25. i 28.10.; 6., 7., 8., 9. i 13.11.1979. (I. G. - 50; J. J. - 53), br. 158-165 (str. 65-68)

Savudrija, 25.2.1975. (I. G. - $4^{15}$ s.; J. J. - $4^{15}$ s.), br. 107 (str. 46/47)

Slum, 28.8.1973. (I. G. - 4 s.; J. J. - 4 s.), br. 61 (str. 26)

Sovinjak, 28.2.1973. (I. G. - 4 s.; J. J. - 4 s.), br. 56 (str. 24)

Stari Pazin, 22.2.1972. (I. G. - 4³; J. J. - $4^{30}$ ), br. 36 (str. 14 i 15)

Sveta Lucija - Škitača, 17.11.1977. (I. G. - 3 s.; J. J. - 3 s.), br. 156 (str. 65)

Sveta Marija na Krasu, 16.5.1974. (I. G. - $10^{30}$ s.; J. J. - $10^{30}$ s.), br. 90 (str. 38)

Sveta Nedjelja Labinska, 27.10.1976. (I. G. - 5 s.; J. J. - 5 s.), br. 147 (str. 61)

Sveti Ivanac nad Rašom, 9.3.1972. (I. G. - $1^{30}$ s.; J. J. - $1^{30}$ ), br. 41 (str. 15)

Sveti Ivan od Šterne, 26.2.1974. (I. G. - $2^{30}$ s.; J. J. - $2^{30}$ s.), br. 77 (str. 33)

Sveti Lovreč - Diminići, 17.11.1977. (I. G. - 3 s.; J. J. - 3 s.), br. 156 (str. 65)

Sveti Lovreč Pazenatički, 23.10.1972. (I. G. - $8^{30}$ s.; J. J. - $8^{30}$ s.), br. 49 (str. 20)

Sveti Martin Labinski, 27.10.1976. (I. G. - 9 s.; J. J. - 9 s.), br. 147 i 155 (str. 61 i 64)

Sveti Petar u Šumi, 19.2.1973. i 6.10.1975. (I. G. - $17^{30}$ s.; J. J. - $17^{30}$ s.), br. 45 i 121 (str. $22 / 23$ i 51$)$

Sveti Vital (Ritošin Brijeg), 20.5.1974. (I. G. - 8 s.; J. J. - 8 s.), br. 92 (str. 39)

Šišan, 29.10.1975. (I. G. - 4 s.; J. J. - 6 s.), br. 125 (str. 53)

Šterna, 24.5.1972. (I. G. - $1^{45}$ s.; J. J. - $1^{45}$ s.), br. 47 (str. 19)

Štinjan, 14.11.1975. (I. G. - $2^{30}$ s.; J. J. - $2^{30}$ s.), br. 137 (str. 57)

Šumber, 27.10.1976. (I. G. - 3 s.; J. J. - 3s.), br. 146 (str. 60 i 61)

Tar, 26.2.1974. (I. G. - 5 s.), br. 80 (str. 34)

Tinjan, 7.3.1972. (I. G. - 4 s.; J. J. - 4 s.), br. 39 (str. 15)

Trviž, 21.2.1972. (I. G. - 5 s; J. J. - 5 s.), br. 35 (str. 14)

Tupljak, 26.11.1971. (I. G. - 8 s.), br. 34 (str. 13) 
Umag, 23. i 29.10.1974. (I. G. - 25 s.; J. J. - 25 s.), br. 105 i 106 (str. 45 i 46)

Valtura, 14.11.1975. (I. G. - 4 s.; J. J. - 4 s.), br. 135 (str. 56)

Višnjan, 6.3.1974. (I. G. - 2 s.; J. J. - 2 s.), br. 81 (str. 35)

Vižinada, 20. i 21.3.1974. (I. G. - 12 s.; J. J. - $18^{30}$ s.), br. 86 i 87 (str. 37)

Vodnjan, 20. i 25.10.1976. (I. G. - 11 s.; J. J. - $15^{30}$ s.), br. 144 i 145 (str. 60)

Vranja, 28.10.1980. (I. G. - 7 s.; J. J. - 7 s.), br. 168 (str. /69 i 70/)

Vrsar, 20.2.1974. (I. G. - $7^{30}$ s.; J. J. - $7^{30}$ s.), br. 74 (str. 31/32)

Vrh, 1.3.1973. (I. G. - 4 s.; J. J. - 4 s.), br. 57 (str. 24)

Zamask, 14.3.1972. (I. G. - $3^{15}$ s.; J. J. - $3^{15}$ s.), br. 43 (str. 17)

Zarečje, 7. i 22.10.1971. (I. G. - 2 s.), br. 17 (str. 7) i 22 (str. 9)

Završje, 24.5.1972. (I. G. - 5 s.; J. J. - 5 s.), br. 46 (str. 19)

Zrenj, 24.5.1972. (I. G. - $2^{30}$ s.; J. J. - $2^{30}$ s.), br. 48 (str. 19)

Žbandaj, 26.2.1974. (I. G. - $4^{30}$ s.; J. J. - $4^{30}$ s.), br. 79 (str. 34)

Žminj, 9.3.1972. i 9.-11.9. 1975. (I. G. - 13³0 J. J. - 20 s.), br. 42, 119 i 120 (str. 17 i 51)

\section{UMJESTO ZAKLJUČKA}

(mr. sc. Ilija Jakovljević)

Pisana ostavština mons. Ivana Graha, svećenika Porečke i Pulske biskupije, župnika Gračišća, Ližnjana i Šišana, kapelana Njegove Svetosti pape Bendikta XVI., prepozita Pulskoga kaptola, povjesničara i arhivista, danas je samo djelomice sačuvana i nalazi se kod mr. sc. Ilije Jakovljevića. Nažalost, velik dio pisama, zapisa, knjiga nije sačuvan. Među sačuvanom se ostavštinom, a još neobjavljenom, nalazi i Dnevnik rada koji su vodili mons. Ivan Grah i mr. sc. Jakov Jelinčić prigodom sređivanja arhivskoga gradiva župa Porečke i Pulske biskupije i Pazinske apostolske administrature ${ }^{69}$ od 1970. do 1980. godine.

Mi, prijatelji i poštovatelji mons. Ivana Graha: Elvis Orbanić, Jakov Jelinčić i Ilija Jakovljević odlučili smo objaviti Dnevnik rada. Zahvalan sam mr. sc. Jakovu Jelinčiću što je prepisao Dnevnik rada te napravio potrebne bilješke i uvod.

Čitajući Dnevnik rada, dolazimo do nekoliko važnih spoznaja: o kojem je arhivskom gradivu riječ, u kakvu se stanju nalazi, kako je sređeno, nalazi li se koji značajniji dokument $\mathrm{u}$ tom fondu i puno drugih detalja. Budući da gradivo nije uvijek bilo moguće sređivati u župama, mons. Grah ga je znao uzeti sa sobom u Gračišće i tamo sređivati, sam ili s g. Jelinčićem. Tu se vidi koliko su svećenici imali povjerenja u mons. Graha i g. Jelinčića.

69 Sveta stolica je, nakon što je talijanski parlament ratificirao Pariški mirovni ugovor u rujnu 1947., imenovala administratora za jugoslavenski dio Tršćansko-koparske biskupije jer je tadašnjem tršćansko-koparskom biskupu mons. Antoniju Santinu bila onemogućena redovita crkvena uprava njegovom biskupijom. Bulom Locum beati Petri iz 1978. godine Pazinska administratura pripojena je Porečkoj biskupiji. 
Kad su mons. Grah i g. Jelinčić započeli svoj rad na sređivanju crkvenih arhiva »na području hrvatskog dijela Istre ima 136 župnih i kapelanijskih arhiva, 13 dekanatskih, 1 biskupijski u Poreču i 1 Apostolske administrature u Pazinu (...) Zatim dolaze kaptolski arhivi koji su svi zatvoreni ili mrtvi a ima ih 15. Ima desetak arhiva kolegijalnih. $\aleph^{70}$ Međutim, nije uvijek sve lako išlo i arhivi su nekih župa ostali nesređeni. Sam mons. Grah u pismu mr. sc. Iliji Jakovljeviću, tada pročelniku Biskupijskoga vijeća za arhive Porečke i Pulske biskupije do 12. kolovoza 2010., ovim je riječima opisao njihov rad: »Istina je da smo gosp. Jakov Jelinčić i ja od 1970. do 1980. inventarizirali arhivsku građu istarskih župa, ali ne svih. Razloge neću navoditi. Čekao nas je još rad u Biskupijskom arhivu u Poreču, ali su biskupa Nežića progonile neke sumnje te smo odustali od našeg dobrovoljnog i volonterskog rada. U popisu su izostale i neke župe na Bujštini, ali o tome ne želim pisati (...) Naša je nakana bila sastaviti inventar građe Župnih arhiva, a stručnu obradu prepustiti budućim istraživačima. Svakako smatram da smo našim zalaganjem dali jedan doprinos ljubiteljima naše prošlosti.« Na temelju relevantnih dokumenata iz crkvenih arhiva mons. Božo Milanović sa suradnicima predstavio je Međunarodnoj komisiji za razgraničenje kakvo je stanje o etničkoj pripadnosti Istre.

Djelomice su za vrijeme biskupa mons. Antuna Bogetića i mons. Ivana Milovana mons. Ivan Grah i mr. sc. Jakov Jelinčić sredili Arhiv biskupije u Poreču, koji je za vrijeme mons. dr. Dražena Kutleše prenesen u nove prostorije pod stručnim vodstvom doktorandice Branke Poropat. U novije su vrijeme uz pomoć Državnoga arhiva u Pazinu sređeni određeni župni arhivi, ali uvijek na temeljima i popisima mons. Ivana Graha i mr. sc. Jakova Jelinčića. Radi pravednosti, potrebno je ovdje spomenuti još dvojicu zaslužnih ljudi, koji su na jedan način omogućili da je gradivo istarskih župa popisano: mons. dr. Dragutina Nežića, biskupa porečkoga i pulskog te dr. h. c. Dražena Vlahova, tada direktora Historijskoga arhiva u Pazinu (danas: Državnoga arhiva u Pazinu).

\section{Terenski rad po župama}

Župnici su tijekom povijesti, kao i danas, upravljali s više župa te se gradivo prenosilo iz župe u župu. »Poteškoće u radu sastojale su se u tome što je često bilo nemoguće ustanoviti razgraničenje fondova, pogotovo u manjim župama, jer se administracija ponekad vodila zajedno za dvije ili tri manje župe. Gdje god je to bilo moguće fondovi su kompletirani (Cerovlje, Borut, Pazinski Novaki, Zarečje), ali je zbog pomanjkanja vremena, a ponekad i stvarne nemogućnosti radi srašćenosti dvaju ili više fondova u jednu cjelinu to bilo nemoguće u nekim fondovima. $\ll^{71}$ Tijekom desetogodišnjega rada mons. Ivan Grah i mr. sc. Jakov Jelinčić sredili su arhivsko gradivo ne samo župa nego i drugih pravnih osoba Katoličke Crkve: kaptola, dekanata, kapelanija... Pri sređivanju držali su se načela da ne diraju »u raniji način odlaganja građe: u radu smo naišli na različito odlaganja spisa

70 Ivan GRAH, »Sadašnje stanje crkvenih arhiva u Istri«, VHARIP, sv. 17, Rijeka, 1972., str. 411.

71 Jakov JELINČIĆ, »Savjetovanje o crkvenim arhivima za kler u Pazinu«, VHARIP, sv. 16, Rijeka, 1971., str. 388 . 
$\mathrm{u}$ austrijskom i u mletačkom dijelu Istre, u većim i manjim fondovima. $\aleph^{72} \mathrm{Uz}$ sređivanje, kako se vidi iz Dnevnika rada, oni su nastojali arhivsko gradivo, ako je pripadalo drugoj pravnoj osobi, njoj vratiti.

Prema Dnevniku rada mons. Ivan Grah i mr. sc. Jakov Jelinčić sredili su gradivo 107 župa Porečke i Pulske biskupije te Pazinske administrature, gdje nismo ubrojili arhive drugih pravnih osoba. Nije također ubrojeno ni ono vrijeme kad su išli na dogovore sa župnicima glede sređivanja arhiva. Kako je iz Dnevnika rada vidljivo, popisivači su najveći dio vremena boravili na terenu u hladnim periodima godine, a gradivo se često nalazilo u sakristijama, na tavanima župnih crkava i u kućama. Često su bili nikakvi uvjeti za rad, ali velika ljubav prema arhivi bila je veća od svih izvanjskih neprilika.

\section{Pisana ostavština mons. Ivana Graha}

Mons. Ivan Grah ostavio je velik trag u izučavanju povijesti ove partikularne Crkve, kao i povijesti XX. stoljeća Istre. U crkvenim krugovima njegova arhivska djelatnost više se gleda, ili se gledala, pod vidom povijesnoga rada. Malo se zna, u široj crkvenoj i arhivističkoj javnosti, da je mons. Ivan Grah prvotno bio svećenik pa arhivist. Godinama je bio pročelnik Vijeća biskupije porečke i pulske za arhive i knjižnice te član Međunarodnoga udruženja crkvenih arhivista u Vatikanu. Mons. Grah je u arhivima vidio zakopano bogatstvo koje je potrebno istražiti kako bi se mogla graditi bolja budućnost. Istina je za njega bila jedina nit vodilja u pisanju, iako ponekad nije bilo lako reći istinu onome kome nije bilo stalo do istine.

Ovaj Dnevnik rada donosi dio daška rada naših neumornih zaljubljenika u arhivistiku i arhive. Utrli su put u sređivanju crkvenih arhiva, a sad mogu samo izgovoriti riječi: »Pošalji, Gospodine, radnika na njivu svoju.«

\section{SAŽETAK \\ Dnevnik rada \\ popisivanja gradiva crkvenih arhiva Porečke i Pulske biskupije te Pazinske apostolske administrature}

(18. prosinca 1970. - 28. listopada 1980.)

Tko se god bavi lokalnom poviješću zna da su crkveni arhivi bogat i nenadomjestiv izvor za proučavanje mjesta u kojem je gradivo nastalo. Treba znati da su crkveni arhivi strogo zaštićeni kanonskim propisima Katoličke crkve. Često se događa da su upravo crkveni dokumenti jedini izvor za lokalnu povijest, u slučajevima kada su arhivi nastali djelovanjem državnih i inih civilnih organa uništeni. Godine 1970., dogovorom između Historijskoga arhiva u Pazinu (danas: Državni arhiv u Pazinu - DAPA) i Porečke i Pulske biskupije i Pazinske apostolske administrature, započelo je popisivanje svih crkvenih ar-

72 Ivan GRAH - Jakov JELINČIĆ, »Kratak pregled građe crkvenih arhiva Istre«, u: VHARIP, sv. 23, Rijeka, 1980., str. 265. 
hiva na području navedenih crkvenih organizacija. Dvojica su arhivskih djelatnika, jedan imenovan s crkvene strane (svećenik Ivan Grah), a drugi sa strane Arhiva (profesor Jakov Jelinčić, arhivist), u vrijeme sređivanja i popisivanja navedenih crkvenih arhiva vodili Dnevnik koji je predmet ovoga rada. Vremenski je raspon Dnevnika od 18. prosinca 1970. do 28. listopada 1980. godine. Jakov Jelinčić prepisao je Dnevnik sa svim pogreškama i osobitostima te je priredio $\mathrm{i}$ »Kazalo« sjedišta u kojima su se u vrijeme njihova rada nalazili crkveni arhivski fondovi, s naznakom dana kada je fond bio u obradi, sati utrošenih za sređivanje i popisivanje svakoga pojedinog djelatnika, potom rednoga broja pojedinoga mjesta i stranice Dnevnika na kojoj se izvješće o radu nalazi. Zaključno je poglavlje ovoga rada napisao mr. sc. Ilija Jakovljević.

Jakov Jelinčić u »Uvodu«, pored isticanja uloge velečasnoga Graha, posebno naglašava zasluge blagopokojnoga porečkog i pulskog biskupa dr. Dragutina Nežića, zatim tadašnjega direktora Arhiva Hrvatske (danas: Hrvatski državni arhiv) Bernarda Stullija i tadašnjega direktora Historijskog arhiva u Pazinu (danas: Državni arhiv u Pazinu) profesora Dražena Vlahova. Ilija Jakovljević u zaključnom poglavlju govori o Grahovim i Jelinčićevim zaslugama, naglašavajući posebno ulogu mons. Graha kao povjesničara i arhivista.

\section{SUMMARY \\ The logbook \\ of the listing of the archival material of the church archives of the Diocese of Poreč and Pula and of the Pazin Apostolic Administration}

\section{(18 December 1970 - 28 October 1980)}

Whoever deals with local history knows that church archives are abundant and irreplaceable sources for studying the place where the archival material was created. It should be noted that the church archives are strictly protected by the canonical regulations of the Catholic Church. It is often the case that church documents are the only source for local history, in cases where archives created by the activity of state and other civilian organisations were destroyed. In 1970, following the agreement made between the Historical Archives in Pazin (today: the Pazin State Archives - DAPA) and the Diocese of Poreč and Pula and the Pazin Apostolic Administration, the listing of all church archives in the area of the two church organizations commenced. Two archival workers, one named by the Church (Ivan Grah, priest), and the other by the Archives (Jakov Jelinčić, archivist), during the time they were active organising and listing the church archives maintained the Logbook, which is the subject of this paper. The time span of the Logbook ranges from 18 December 1970 to 28 October 1980. Jakov Jelinčić copied the Logbook with all the mistakes and peculiarities and prepared the "Index" of the offices where, at the time of their work, church archival fonds were housed, with the indication of the day the fonds was being processed, the hours spent arranging and listing by every employee, followed by the 
number of individual places and pages of the Logbook where an activity report is located. The closing chapter of this paper was written by Ilija Jakovljević.

In the "Introduction", in addition to emphasizing the role of Reverend Grah, Jakov Jelinčić underlines the merits of the late Bishop of Poreč and Pula Dragutin Nežić, of the then manager of the Archives of Croatia (now Croatian State Archives) Bernard Stulli and the then manager of the Croatian Historical Archives in Pazin (today: The State Archives in Pazin) Dražen Vlahov. In the closing chapter, Ilija Jakovljević speaks about Grah's and Jelinčićs merits, emphasizing in particular the role of Msgr. Grah as a historian and archivist.

\section{RIASSUNTO \\ Registro di lavoro per la registrazione del materiale degli archivi ecclesiastici della Diocesi di Parenzo e Pola nonché dell'Amministrazione apostolica di Pisino (18 dicembre 1970 - 28 ottobre 1980)}

Chiunque si occupi della storia locale sa che gli archivi ecclesiastici sono una fonte ricca e insostituibile per lo studio del luogo in cui è stato prodotto il materiale. Bisogna sapere che gli archivi ecclesiastici sono rigorosamente protetti dalle norme canoniche della Chiesa cattolica. Succede spesso che proprio i documenti ecclesiastici siano la fonte unica per la storia locale, nei casi in cui gli archivi vengono distrutti tramite l'azione di autorità statali e civili. Nell'anno 1970, con l'accordo tra l'Archivio storico di Pisino (oggi: Archivio di Stato di Pisino - DAPA/ASP) e la Diocesi di Parenzo e Pola e l'Amministrazione apostolica di Pisino, è iniziata la registrazione di tutti gli archivi ecclesiastici sul territorio delle citate organizzazioni ecclesiali. Due operatori archivistici, uno nominato da parte della chiesa (il sacerdote Ivan Grah), e l'altro da parte dell'Archivio (il professore Jakov Jelinčić, archivista), durante l'ordinamento e la registrazione dei citati archivi ecclesiastici, hanno redatto il Registro, oggetto del presente testo. L'arco temporale del Registro va dal 18 dicembre del 1970 al 28 ottobre del 1980. Jakov Jelinčić ha trascritto il Registro con tutti gli errori e particolarità ed ha inoltre redatto l' "Indice" delle sedi in cui si trovavano i fondi archivistici ecclesiastici nel periodo del loro lavoro con l'indicazione del giorno in cui il fondo era in elaborazione, delle ore impiegate da parte di ogni operatore per l'ordinamento e la registrazione, poi del numero d'ordine di ogni parte e di pagina del Registro sulla quale si trova il rapporto sul lavoro. Il capitolo finale di questo testo è stato scritto da Dott. Ilija Jakovljević.

Jakov Jelinčić nell' "Introduzione“, oltre a sottolineare l'importante ruolo del venerabile Grah, sottolinea in particolare i meriti del compianto vescovo di Parenzo e Pola, Dott. Dragutin Nežić, di Bernard Stulli, direttore dell'epoca dell'Archivio della Croazia (oggi Archivio di Stato croato), e del professor Dražen Vlahov, direttore dell'epoca dell'Archivio storico di Pisino (oggi: Archivio di Stato di Pisino). Ilija Jakovljević nel capitolo finale parla dei meriti di Grah e Jelinčić, sottolineando in particolar modo il ruolo del Monsignor Grah in quanto storico e archivista. 